Pamukkale University Journal of Social Sciences Institute

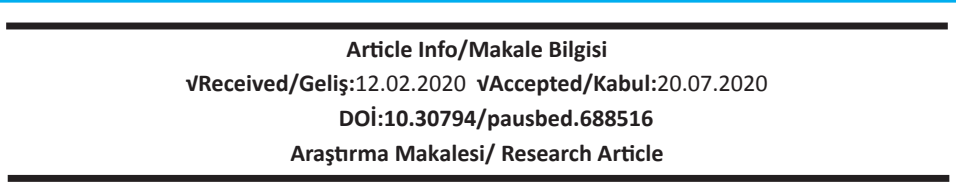

Başalp, A. A. ve Altın Gülova, A. (2021). "Yönetici Yetkinliklerinin Geliştirilmesinde Zorlu Görevler ve Erişimi ile Öğrenme Odaklılık ve Geri Bildirimin Rolü", Pamukkale Üniversitesi Sosyal Bilimler Enstitüsü Dergisi, Sayı 43, Denizli, ss. 39-40.

\title{
YÖNETICi YETKINLIKLERININ GELIŞTIRILMESINDE ZORLU GÖREVLER VE ERIŞiMi íL ÖĞRENME ODAKLILIK VE GERI BILDIRIMIN ROLÜ
}

\author{
Afet Ayçe BAŞALP*,Asena ALTIN GÜLOVA**
}

Öz

\begin{abstract}
Işletmeler hem ulusal hem de uluslararası alanda rekabet edebilmek için yönetici geliştirme programlarına yatırım yapmaktadırlar. Yönetici geliştirme programlarının en önemli parçalarından birisi de yönetici yetkinliklerini geliştirmektir. Yönetici yetkinliklerinin geliştirilmesinin unsurları ise; zorlayıcı yönetsel görevler, gelişimsel özelliğe sahip yönetsel görevlere erişim, geri bildirim ve öğrenme odaklılıktır. Yapılan çalışmalarda yöneticilerin gelişmelerine yönelik verilen zorlayıcı görevlerin, öğrenme odaklııık, zorlu görevlere erişim ve geri bildirim gibi kav-ramların yönetici yetkinlikleri üzerindeki pozitif ilişkisi olduğu tespit edilmiştir. Bu çalışma, birbirlerinden bağımsız olarak ortaya çıkan söz konusu değişkenlerin yönetici yetkinlikleri üzerindeki etkisi ve ilişki düzeylerini araştırmaktadır.
\end{abstract}

Anahtar Kelimeler: Yönetici yetkinlikleri, Yöneticilere verilen zorlu görevler, Zorlu görevlere erişim, Geri bildirim alma, Öğrenme odaklılık

\section{THE ROLE OF GOAL ORIENTATION AND FEEDBACK WITH DEVELOPMENTAL CHALLENGE AND ACCESS IN DEVELOPING MANAGERIAL COMPETENCIES}

\section{Abstract}

Businesses invest in executive development programs to compete both nationally and internationally. One of the most important parts of executive development programs is to develop end-state competencies. The elements of the development of end-state competencies are; compelling managerial tasks are access to develop mentally managerial tasks, feedback and learning orientation. In the studies carried out, it has been determined that the compelling tasks given for the development of the manager shave a positive relationship on the management competencies of the concepts such as learning focus, Access to highly developmental managerial assignment and feedback. This study investigates the effect and relationship levels of the sevariables, which ocur independently of each other, on end-state competencies.

Keywords: Managerial end-state competencies, Developmental challange, Access to highly developmental managerial assignment, Feedback, Goal orientation.

\footnotetext{
* Arş. Gör. Dr. Manisa Celal Bayar Üniversitesi, Uygulamalı Bilimler Fakültesi, Uluslararası Ticaret Bölümü, MANiSA. e-posta: ayce.basalp@cbu.edu.tr (https://orcid.org/0000-0003-2914-0632)

** Prof. Dr. Manisa Celal Bayar Üniversitesi, îktisadi ve İdari Bilimler Fakültesi, İ̧letme Bölümü, MANiSA. e-posta: asena.gulova@cbu.edu.tr (https://orcid.org/0000-0002-0094-8227)
} 


\section{GíRiş}

İşletmeler hem ulusal hem de uluslararası alanda rekabet edebilmek için yönetici geliştirme programlarına yatırım yapmaktadırlar. Mc Call ve Hollenbeck'in (2002:127) “yöneticilik iş başında tecrübe ile öğrenilir" ifadesinde belirtildiği üzere formal olan iş başındaki programlar yöneticilerin öğrenmesinde önemli yer taşımaktadır. Bunun yanı sıra ABD'de her yıl işletmelerin ayırdığı bütçe ise yönetici geliştirme için yıllık olarak 2007 yılında 16,5 trilyon dolardan, 2016 yılında 45 trilyon dolara yükselmiştir. 2004'te yapılan anket sonuçlarına göre (Bolt, 2007) üst düzey yöneticiler için harcanan paranın 7 milyar dolar olduğu, bu bütçenin içerisinde formal programlar, koçluk ve zorlu görevlerin dahil olduğu belirtilmiştir. Harvard ve Stanford Üniversitelerinde yapılan araştırmalara göre ABD’deki işletmelerin 2016 yılında yönetici geliştirme programlarına 31 milyar dolarlık harcama yaptıkları tespit edilmiştir (Wakefield vd., 2016: 27). ABD Sosyal Güvenlik Bakanlığı'nın 24 Mayıs 2017'de yaptığı basın açıklamasında "İ̧̧ ve yönetici geliştirme programlarına ABD bütçesinde ayrılan 1,6 milyar doların (2016), \%40 oranında arttırıldığı ve 2,7 milyar dolara çıkarıldığı belirtilmiştir" (CNN Money Report; 2017). Bu yatırımların birçoğu iş dışı eğitim programları ve aktivitelerine (gezi, yurt dışı eğitimleri gibi çalışanlar ile yapılan sosyal aktiviteler), kurslara, yetiştirme programlarına ve koçluk programlarına ayrılmıştır. Yukarıda açıklamasına yer verilen çalışmalara bakıldığında, bu çalışma ile Türkçe literatürdeki eksik bırakılan konu olan yöneticilere verilen zorlayıcı görevlerin neler olduğu ve bu alan yazınındaki çalışmaların kısıtlı olduğu sonucuna varılmaktadır. Bu çalışma ile yönetici yetkinliklerinin geliştirebilir olduğu aynı zamanda yönetici geliştirme programlarına hem üniversitelerin hem de kamu kurumlarının destek vermesinin önem taşıdığı vurgulanmıştır.

Yönetici geliştirme teorisinin temelinde, yönetici yetkinliği ve yetenek kavramları öne çıkmaktadır (McCall, 1988; McCauley vd., 1994). Yönetici yetkinliklerinin geliştirilmesi amacıyla yapılan çalışmalarda; zorlu görevlerin yöneticilere verilmesi ve geri bildirimde bulunulması da dikkati çeken diğer kavramlar olarak karşımıza çıkmaktadır. Dragoni ve diğerlerine (2009: 731) göre yöneticilerin performanslarını arttırmak için yöneticilere zorlu görevler verilmesi gerekmektedir ve geleneksel modelde işi iş başında öğrenmek ve öğretmek önemlidir. Tesluk ve Jacobs'a (1998) göre de bir işi öğrenebilmek için yöneticinin o işi iş başında uygulaması gerekmektedir (Dragoni vd., 2009: 732).

Yöneticilik yetkinliklerini geliştirmek için iş başında öğrenmenin büyük önem taşıdığı bilinmektedir. McCall ve Hollenbeck'in (2002: 127) "yöneticilik iş başında ve tecrübe ile öğrenilir" ifadesinde belirtildiği üzere iş başında öğrenmenin temelinde tecrübe bulunmaktadır. İş başında öğrenmeyi kapsayan yöneticilik geliştirme programlarında \%70 başarı sağlanırken, iş dışındaki eğitimlerde \%10 başarı sağlandığı tespit edilmiştir (McCall, 2004). İş ve yöneticiliğin iş başındayken öğrenildiğine (McCall vd., 1988: 15) dikkat çekilirken, yapılan bir diğer çalışmada (Öner, 2008) iş başında ve iş dışında yapılan eğitimlerin değerlendirilmesi gerekliliği ele alınmış, bu eğitimlerin neler olduğu ve yönetici geliştirmeyi nasıl etkilediğinin tespit edilmesi gerektiği vurgulanmıştır. Bu bağlamda yönetici geliştirmede iş başında eğitim çeşitlerinden hangilerinin tercih edileceğinin doğru analiz edilmesinin önemi ortaya çıkmaktadır. Diğer taraftan yönetici geliştirme programlarının hem yöneticinin kariyeri hem de örgütün verimli ve başarılı bir şekilde yönetilmesindeki anahtar rolünün daha iyi anlaşılması gerekmektedir. Türkçe yönetim ve organizasyon literatüründe, yönetici geliştirme programları ve yöneticileri geliştirmeye yönelik etkenleri araştıran sınırlı sayıda çalışma mevcuttur (Budak, 2008; Eren, Tokgöz ve Gül, 2013; Yılmaz, Alpkan ve Bulut, 2009). Öte yandan bu çalışma ile yönetici geliştirmede, iş başında eğitimin ve iş başında edinilen önemi de tespit edilmiştir. Aynı zamanda yöneticilere verilen zorlu görevlerin yönetici yetkinlikleri üzerindeki etkisi de tespit edilmiştir. Buradan hareketle, bu çalışmanın ana konusu yöneticilere verilen zorlayıcı görevler ölçeğinin Türkçeye adapte edilmesi ve geliştirilmesidir. Yönetici yetkinliklerinin yöneticilere verilen zorlayıcı görevlerin üzerindeki etkisini tespitini yapmaktır. Bu çalışmada; literatür incelemesi yapılırken yöneticilere verilen zorlayıcı görevler üzerine yapılmış olan çalışmalar üzerine odaklanmıştır. Literatür anlamında yazındaki bu eksiği gidermek temel amacımızdır. Bundan sonra yapılacak olan çalışmalar yöneticilere verilen zorlayıcı görevlerin diğer değişkenler (iş tatmini, örgütsel, bağlıık, çalışan yaratıcılığı,inovasyonv.b.) üzerindeki etkisini incelemek olmalıdır.

\section{LITERATÜR INCELEMESI}

Wilson ve Yip'e göre (2010: 63), verimli yöneticilerin kariyerleri incelendiğinde, kendilerini bu noktaya kadar getiren faktörler; üstlenmiş oldukları zorlu görevler, geliştirici ilişkiler ve yaşadıkları zor durumlardır ve 
yazarlar iyi ve faydalı bir yönetici olabilmek için iş başında zorlu görevler almak ve kazanılan tecrübelerden ders çıkarmak önemlidir. Örgütler/yöneticiler/birimler zorlu görevlerin ve kazandıkları tecrübelerin yöneticileri geliştiren en önemli iki öğrenme aracı olduğunu bildikleri düşünülmektedir. McCall ve diğerlerine (1997: 68) göre zorlu görevlerin içeriği şu şekildedir; Aşağıdaki tabloda yöneticilere verilen zorlu görevlerin neler olduğu yer almaktadır. Buradan hareketle yöneticilerin geliştirilmesini sağlamak için verilmesi gereken görevler sırasıyla aşağıda verilmiştir. Zorlu görevleri açıklamak gerekir ise; yeni yönetici olmuş kişilere verilen görevler, ilk deneyimleri, işletme içerisinde daha önce yapılmamış ya da öngörülmemiş görevlerin verilmesi, ast -üst ilişkilerindeki görev tanımları veya görev artışları, çeşitli kaos yaratabilecek sorunlar ve krizler, kişisel yaşanan travmalar, personelin yaşadığı kişisel problemler ve görev başındaki başarısızlıklarla yöneticilerin mücadelesi örnekleri verilebilmektedir. Bir yöneticinin gerçekten gelişim yaşaması için aşă̆ıda sayılan görevlerine ne ölçüde yerine getirdiği performansı ile ilişkilidir.

Tablo 1: Yöneticilere verilen zorlu görevler

\begin{tabular}{|l|l|}
\hline yeni yöneticilere verilen görevler & kaçırılan iş ve terfi firsatları \\
\hline ilk süpervizörlük görevi & personel verimliliğinin düştüğü zaman dilimleri \\
\hline işletme içerisinde yapılan ilk değişimler & farklı pozisyon ve görevlerde çalışmak \\
\hline yeni projelerin sorumluluğu & kişisel travmalar (hastalık, ölüm, boşanma) \\
\hline astların sayısındaki artış & rol model olma \\
\hline astların rotasyonunu gerçekleştirme & iş başındaki eğitimlerdeki başarı \\
\hline başarısız iş süreçlerinden çıkarılan sonuçlar & kişisel deneyimler \\
\hline & işletme içi önceliklerin değişimidir \\
\hline
\end{tabular}

Literatür incelemesinde yöneticilere verilen zorlu görevlere ilişkin yapılan araştırmaların bir özeti ise tablo 2 ve 3 'te yer almaktadır.

Tablo 2: Yönetici Geliştirme Üzerine Yapılan Tez Çalışmaları ve Bulgular (1999-2018)

\begin{tabular}{|c|c|c|c|}
\hline Çalışmanın Adı & Örneklem & Kullanılan Ölçekler & Bulgular \\
\hline $\begin{array}{l}\text { Türk İlaç Endüstrisinde Yönetici } \\
\text { Geliştirme Faaliyetleri } \\
\text { Serap Hepkaya Yüksek Lisans Tezi } \\
\text { (2000) }\end{array}$ & $\begin{array}{l}31 \text { İlaç Firmasının İnsan } \\
\text { Kaynakları Müdürleri veya } \\
\text { Personel Müdürleri. }\end{array}$ & $\begin{array}{l}\text { Yönetici Geliştirme } \\
\text { ile ilgili 1999'a kadar } \\
\text { yapılan çalışmalar } \\
\text { incelenmiş olup o } \\
\text { çalışmalardan (Marşap, } \\
\text { 1992; Gündüz, 1994; } \\
\text { Göncüler, 1996; Uygur, } \\
\text { 1996) alınan sorularla } \\
\text { anket formu olarak } \\
\text { hazırlanmıştır. }\end{array}$ & $\begin{array}{l}\text { 1) Türkiye'deki ilaç } \\
\text { firmalarının yönetici } \\
\text { geliştirmesi için } \\
\text { uygulanan hizmet içi } \\
\text { (iş başında eğitim) } \\
\text { eğitimlerin katkısı } \\
\text { önemli bulunmuştur. } \\
\\
\text { 2) Yöneticilerin gelişmesi } \\
\text { için yetki devri } \\
\text { (zorlu görevlere } \\
\text { katılım) yönetime } \\
\text { katılmalarının önemi } \\
\text { vurgulanmıştr. }\end{array}$ \\
\hline $\begin{array}{l}\text { Türk Kamu Yönetiminde Yönetici } \\
\text { Geliştirme } \\
\text { İbrahim Avcı Doktora Tezi (2004) }\end{array}$ & $\begin{array}{l}\text { Türkiye'de görev yapmakta } \\
\text { olan (valiler hariç) } 146 \\
\text { Mülki İdari Amiri. }\end{array}$ & $\begin{array}{l}\text { - Yönetici Yeterlilikleri } \\
\text { (Peker, 1994) } \\
\text { - Mesleki } \\
\text { Değerlendirme } \\
\text { (Peker,1994) }\end{array}$ & $\begin{array}{l}\text { Temel eğitim becerilerinin } \\
\text { kazanımı için en aktif } \\
\text { yöntemin konferanslar } \\
\text { dışında iş başında } \\
\text { uygulamalı eğitimler } \\
\text { olduğu düşünülmektedir. }\end{array}$ \\
\hline
\end{tabular}




\begin{tabular}{|c|c|c|c|}
\hline $\begin{array}{l}\text { Management Development In } \\
\text { Human Resource Management } \\
\text { And A Research } \\
\text { Hasan Başusta Yüksek Lisans Tez } \\
\text { Çalışması (2006) }\end{array}$ & $\begin{array}{l}7 \text { yönetici ve } 1 \text { Genel Müdür } \\
\text { örnek olay incelemesi. } \\
\begin{array}{l}\text { Allport İşletmesi (havayolu } \\
\text { şirketi) }\end{array}\end{array}$ & $\begin{array}{l}\text { İşletmenin Yönetici } \\
\text { geliştirme Programı } \\
\text { ile ilgili tüm dataları } \\
\text { (eğitimlerin içeriği, } \\
\text { süresi, katkısı, faydası, } \\
\text { eksik yönleri v.b.) } \\
\text { ve } 86 \text { yöneticiden } \\
\text { yönetici geliştirme } \\
\text { tekniği hakkında bilgi } \\
\text { alınmıştır. }\end{array}$ & $\begin{array}{l}\text { 1)Her bir yönetici } \\
\text { gelisstirme tekniği } \\
\text { hakkında bilgi sahibi } \\
\text { olunmuştur. } \\
\text { 2) Yönetici geliştirme } \\
\text { tekniklerinden; iş } \\
\text { başında verilen } \\
\text { eģitimlerin (özellikle } \\
\text { mentorluk, role } \\
\text { play, örnek olay v.b.) } \\
\text { daha yararlı olduğu } \\
\text { görülmüştür. }\end{array}$ \\
\hline $\begin{array}{l}\text { The Medıatng Effect of } \\
\text { Organızational Justice: Moderatıng } \\
\text { Roles of Sense of } \\
\text { Coherence and Job Complexıty on } \\
\text { The Relationshıp Between Servant } \\
\text { Leadershıp, and Work Engagement } \\
\text { Zeynep Hale Öner Doktora Tezi } \\
\text { (2008) }\end{array}$ & $\begin{array}{l}\text { İstanbul'da faaliyet } \\
\text { gösteren } 26 \text { işletmede } \\
\text { çalışan } 305 \text { orta düzey } \\
\text { yönetici. }\end{array}$ & $\begin{array}{l}\text { - Hizmetkar yöneticilik } \\
\text { Ölçeği John E } \\
\text { Barbuto, JR. W. } \\
\text { Wheeler(2002); Page } \\
\text { ve Wong (2000); } \\
\text { RobDennis (2004). } \\
\\
\text { - Tutarlılık anlayışı } \\
\text { ölçeği (Antonovsky, } \\
\text { 1987). }\end{array}$ & $\begin{array}{l}\text { 1) Çalışmada } \\
\text { hizmetkar yöneticilik } \\
\text { özelliklerinden, } \\
\text { literatürde belirtilen } \\
\text { yöneticinin, vizyona } \\
\text { yönelik kavramsal } \\
\text { düşünebilme } \\
\text { yeteneği, ahlak ve } \\
\text { etik tutumu, sosyal } \\
\text { sorumluluk olarak } \\
\text { adlandırabileceğimiz } \\
\text { şirket dışı toplum için } \\
\text { bir değer yaratma } \\
\text { özellikleri ise ortaya } \\
\text { çıkmamıştır. }\end{array}$ \\
\hline $\begin{array}{l}\text { İsletmelerde } \\
\text { Performans Değerlendirme, } \\
\text { Geri Bildirim, Kariyer Planlama } \\
\text { ve Örgütsel Bağlıık Arasındaki } \\
\text { İlişkilere Yönelik Bir Araştırma }\end{array}$ & $\begin{array}{l}\text { Gebze Organize Sanayi } \\
\text { Bölgesinde } 76 \text { işletme ve } \\
200 \text { orta düzey çalışandan } \\
\text { oluşmaktadır. }\end{array}$ & $\begin{array}{l}\text { - Performans } \\
\text { değerlendirme } \\
\text { (Torrington ve Heil, } \\
\text { 1995) } \\
\text { - Geri Bildirim (Sherer } \\
\text { ve Adams, 1983) } \\
\text { - Kariyer Planlama } \\
\text { (Sherer ve Adams, } \\
\text { 1983) } \\
\text { - Örgütsel Bağlılık } \\
\text { (Allen ve Meyer, } \\
\text { 1990) }\end{array}$ & $\begin{array}{l}\text { 1) Performans } \\
\text { değerlendirme ve geri } \\
\text { bildirim uygulamaları } \\
\text { ile kariyer planlaması } \\
\text { ölçeğinin alt boyutu } \\
\text { geleceğe odaklılık } \\
\text { arasında pozitif } \\
\text { ve anlamlı bir } \\
\text { ilişki olduğu tespit } \\
\text { edilmiştir. } \\
\text { 2) Performans } \\
\text { değerlendirme ve geri } \\
\text { bildirim uygulamaları } \\
\text { ile kariyer planlamanın } \\
\text { öz değerlendirme } \\
\text { boyutu arasında } \\
\text { pozitif ve anlamlı bir } \\
\text { ilişkinin olduğu sonucu } \\
\text { da ortaya çıkmıştır. }\end{array}$ \\
\hline
\end{tabular}




\begin{tabular}{|c|c|c|c|}
\hline $\begin{array}{l}\text { Yönetici Geliştirme ve Örgüt } \\
\text { Geliştirme: } \\
\text { T.C. Ziraat Bankası A.Ş.'de Bir } \\
\text { Uygulama } \\
\text { Belma Nesrin Durusu Yüksek Lisans } \\
\text { Tez Çalışması (2010) }\end{array}$ & $\begin{array}{l}\text { Bu çalışmada, T.C.Ziraat } \\
\text { Bankası A.ş. yöneticilerinin } \\
\text { liderlik ve yöneticilik } \\
\text { açısından gelişim dereceleri } \\
\text { değerlendirilmiştir. Genel } \\
\text { Müdürlük Birimleri ile, } \\
\text { Ankara1. ve 2. Bölge } \\
\text { Müdürlükleri'ne bağlı } \\
\text { Şubelerdeki yöneticilere } \\
\text { uygulanmıştır. (sayısı } \\
\text { mevcut değildir) }\end{array}$ & $\begin{array}{l}\text { Blake ve Mouton } \\
\text { (1987) yönetsel ölçek } \\
\text { kullanılmıştır. } \\
\text { Drucker, } 2007 \\
\text { Best Practices } \\
\text { in Organization } \\
\text { Development } \\
\text { andChange kitabı } \\
\text { ışığında } 31 \text { önerme } \\
\text { kullanılmıştır. }\end{array}$ & $\begin{array}{l}\text { 1) Yönetici geliştirme, } \\
\text { yöneticilerin beceri, } \\
\text { nitelik ve yönetim } \\
\text { gücü açısından } \\
\text { gelişmesini sağlar. } \\
\text { 2) Yönetici yetiştirmek } \\
\text { için düzenlenen } \\
\text { Bankacılık Okulu ve } \\
\text { yönetici geliştirmek } \\
\text { için düzenlenen 144 } \\
\text { Davranış Geliştirme } \\
\text { Eğitimleri ve Yönetici } \\
\text { Akademisi gibi } \\
\text { eğitimler bankanın } \\
\text { bu konudaki dikkatini } \\
\text { ve başarısını } \\
\text { göstermektedir. }\end{array}$ \\
\hline
\end{tabular}

(Kaynak:Başalp,2018)

Tablo 3. 2001-2018 Yılları Arasında Yönetici Yetkinlikleri Üzerine Yapılan, Örneklem Büyüklüğü 180 Yönetici ve Üzeri Olan Nicel Makale Çalışmaları

\begin{tabular}{|c|c|c|c|}
\hline Çalışmanın Adı ve Yazarı & Örneklem & Kullanılan Ölçekler & Bulgular \\
\hline $\begin{array}{l}\text { The Unlearning of Managerial } \\
\text { Skills: A } \\
\text { Qualitative Study of Executive } \\
\text { Officers } \\
\text { Makoto Matsuo (2017) }\end{array}$ & $\begin{array}{l}\text { Orta ve büyük ölçekli } \\
\text { Japon işletmelerinin } \\
\text { yönetici geliştirme } \\
\text { programlarına katılan } 46 \\
\text { üst düzey yöneticileri }\end{array}$ & $\begin{array}{l}\text { ? Yönetici yetkinlikleri } \\
\text { (Katz,1955) } \\
\text { ? Leadership Pipeline } \\
\text { model, (Charan, Drotter } \\
\text { ve Noel, 2000) } \\
\text { ? Unlearning at } \\
\text { organizational and } \\
\text { individual levels (Tsang } \\
\text { and Zahra, 2008). }\end{array}$ & $\begin{array}{l}\text { Öğrenilen yönetici } \\
\text { yetkinliklerinin \%61 oranında } \\
\text { yöneticilerin karar verme } \\
\text { mekanizmasını geliştirdiği, } \\
\text { \%59 oranında motivasyonu } \\
\text { arttırdığı ve \%35.9 oranında } \\
\text { bilgi aktarımı sağladığı } \\
\text { söylenmiştir. }\end{array}$ \\
\hline $\begin{array}{l}\text { Exploring factors influencing } \\
\text { employees' impression } \\
\text { management feedback-seeking } \\
\text { behavior: The role of managerial } \\
\text { coaching skills and affective trust } \\
\text { Hui-Hsien, Jie-Tsuen (2018) }\end{array}$ & $\begin{array}{l}\text { Taiwan'daki } 5 \text { hizmet } \\
\text { işletmesinde çalışan } 321 \\
\text { orta düzey çalışandan } \\
\text { toplanmıştır. }\end{array}$ & $\begin{array}{l}\text { ? Managerial Coaching } \\
\text { Skills (McLean vd. 2005) } \\
\text { ? MCS and affective trust } \\
\text { in supervisors (McAllister, } \\
\text { 1995) } \\
\text { ? Employee development } \\
\text { (Kim \& Kuo,2015) }\end{array}$ & $\begin{array}{l}\text { Araşttrmacılar, yardımsever } \\
\text { liderliğin çalışanlar ve } \\
\text { denetçiler arasında olumlu } \\
\text { bir duygusal bağ oluşturmaya } \\
\text { katkıda bulunabileceğini } \\
\text { ortaya çıkarmıştır. Çalışanların } \\
\text { koçlarına duydukları güveni } \\
\text { artırabileceklerini tespit } \\
\text { etmişlerdir. }\end{array}$ \\
\hline $\begin{array}{l}\text { The impact of leaders' } \\
\text { technical competence on } \\
\text { employees'innovation and } \\
\text { learning } \\
\text { Nguyen Van Minha, Yuosre F. } \\
\text { Badira, Nguyen NgocQuanband } \\
\text { Bilal Afsarc (2017) }\end{array}$ & $\begin{array}{l}\text { Vietnam'daki } 68 \\
\text { telekomünikasyon } \\
\text { işletmesinde çalışan } \\
52 \text { yönetici ve } 127 \\
\text { çalışandan toplanmıştır. }\end{array}$ & $\begin{array}{l}\text { ? Leader Technical } \\
\text { Competence (De Jong and } \\
\text { Den Hartog, 2010) } \\
\text { ? Innovative Work } \\
\text { Behaviour (Chien, 2007) }\end{array}$ & $\begin{array}{l}\text { Teknolojili sanayilerde, } \\
\text { liderlerin teknik bilgi ve teknik } \\
\text { görevlerini astlarından daha } \\
\text { iyi bir şekilde yerine getirme } \\
\text { yeteneğine teknik yetenek } \\
\text { denilmektedir. }\end{array}$ \\
\hline
\end{tabular}




\begin{tabular}{|c|c|c|c|}
\hline $\begin{array}{l}\text { Intelligence and it simpact on } \\
\text { managerial effectiveness and } \\
\text { career success (evidence from } \\
\text { insurance sector of Pakistan) } \\
\text { Usman Aslam, Muhammad Ilyas, } \\
\text { Muhammad KashifImranand } \\
\text { Ubaid Ur Rahman (2016) }\end{array}$ & $\begin{array}{l}\text { Sigorta şirketlerinde } \\
\text { çalışan } 202 \text { üst } \\
\text { düzey yöneticiden } \\
\text { toplanmıştir. }\end{array}$ & $\begin{array}{l}\text { Cognitive intelligence } \\
\text { scales (Wechsler, 2008); } \\
\text { Culturalin telligence } \\
\text { (Ang, Dyne, Koh ve Ng, } \\
\text { 2007); } \\
\text { Career success scale } \\
\text { (Turban and Dougherty, } \\
\text { 1994); } \\
\text { Managerial Effectivenes } \\
\text { sscale (Gupta, 1996). }\end{array}$ & $\begin{array}{l}\text { İşletmeler dinamik bir iş } \\
\text { ortamı ile karşı karşıyadır, } \\
\text { küreselleşme; durgunluk, } \\
\text { satnn alma, deregülasyonlar, } \\
\text { teknolojik gelişmeler } \\
\text { dolayısıyla önemli karar } \\
\text { alıcılar küresel belirsiz iş } \\
\text { ortamında hayatta kalmak } \\
\text { için daha fazla bilince sahip } \\
\text { olmalıdırlar. }\end{array}$ \\
\hline $\begin{array}{l}\text { How Relevant Is the MBA? } \\
\text { Assessing the Alignment of } \\
\text { Required Curricula and Required } \\
\text { Managerial Competencies } \\
\text { Robert S. RubinandErich C. } \\
\text { Dierdorff (2009) }\end{array}$ & $\begin{array}{l}\text { ABD'de } 373 \text { üniversitede } \\
\text { MBA yapan } 8.633 \\
\text { yöneticiden } \\
\text { toplanmıştir. }\end{array}$ & $\begin{array}{l}\text { Managerial competency } \\
\text { information document } \\
\text { Managing Decision } \\
\text { Managing Human } \\
\text { Capital Organizational } \\
\text { Behavior Managing } \\
\text { Strategy and Innovation } \\
\text { Managing the Task } \\
\text { Managerial Economics } \\
\text { task tekniklerinden } \\
\text { yararlanılmıştr. }\end{array}$ & $\begin{array}{l}\text { MBA programlarının yönetici } \\
\text { geliştirme üzerinde ortalama } \\
\% 70 \text { 'lerde etkisi olduğu } \\
\text { görülmektedir. } \\
\text { Boyut bazında bakıldığında: } \\
\text { İnsan sermayesine }(\% 93,57) \\
\text { ve karar verme süreçlerinin } \\
\text { yönetilmesinde (\%71.31) }\end{array}$ \\
\hline
\end{tabular}

(Kaynak:Başalp,2018).

\section{YÖNTEM}

\subsection{Araştırmanın Amacı ve Önemi}

Bu çalışmanın amacı yöneticilerin gelişmelerine yönelik verilen zorlu görevler, öğrenme odakılı̆̆ı, zorlu görevlere erişiminin ve geri bildirim almanın, yönetici yetkinliklerini geliştirmeye etkilerini ortaya koymaktır.

Türkçe literatürde bu çalışmada kullanılan değişkenlerle ilgili yönetici yetkinlikleri ve yöneticilerin gelişmelerine yönelik verilen zorlu görevler ile ilgili ölçeklerin bulunmaması, çalışma sonucunda yönetici yetkinlikleri, zorlu görevler ölçeği, geri bildirim alma, zorlu görevlere erişim ve öğrenme odaklılık ölçeklerinin Türkçe'ye uyarlanması neticesinde alan yazınına teorik ve uygulamaya yönelik katkı sağlanacağı düşünülmektedir.

Yönetici yetkinliklerinin kavramsallaştırılması ve operasyonel hale getirilmesi yazında Dragoni (2009), McCall(2004) ve McCauley (1994) tarafından detaylı olarak gerçekleştirilmiştir. Bu konu çok geniş içerik ve kapsama sahip olduğundan Türk yazınına kazandırılması faydalı olacaktır. Pilot çalışması Manisa Organize Sanayi Bölgesi'nde orta ve üst düzey yöneticilerden 01.01.2014-03.03.2014 tarihleri arasında veri toplanmıştır. 74 anket e-mail, 50 anket ise yüz yüze olmak üzere toplam 124 anket elde edilmiştir. Toplanan anketlerden ortaya çıkan verilen sonucunda öğrenme odaklıık, zorlu görevlere erişim, yöneticilerin gelişmelerini sağlayan zorlu görevler ve yönetici yetkinlikleri değişkenleri toplanarak, madde sayısına bölünerek tek bir sayı olarak hesaplanmışır. Bu dört değişkenin iç tutarlılık katsayıları ,749 ile ,870 arasında olup, iç tutarlıık gösterdiği görülmektedir. Pilot çalışmada yapılan regresyon analizi sonucunda öğrenme odaklıık ve zorlu görevler, yönetici yetkinlikleri üzerinde \%53 oranında açıklayıcı olmuştur. Pilot çalışmadan sonra bu çalışmaya aşağıdaki şekilde yön verilmiştir.

Makale çalışmasının evreni, Manisa Organize Sanayi Bölgesi'nde faaliyet göstermekte olan 173 firmada çalışan genel müdür (veya yardımcıları) ve bölüm yöneticilerinden oluşmaktadır. Araştırmanın örneklemi ise Manisa Organize Sanayi Bölgesi'nde bulunan 30 firmanın 3 farklı birimindeki 230 orta düzey yönetici ve onların amirlerinden 53 üst düzey yöneticiden oluşmaktadır. Bu çalışmada veriler toplanırken hem departman yöneticilerinden hem de onların amirleri konumundaki Genel Müdür ve yardımcılarından toplanmıştır. Bu şekilde, veriler bağımlı ve bağımsız değişkenden toplandığından ortaya çıkabilecek tarafılık sorununun üstesinden gelinmiştir. Doktora tez çalışması olan bu çalışmanın anketleri, Ocak 2018- Haziran 2018 aralığında elden anket dağııımı ve e-mail yöntemiyle toplanmıştır. 


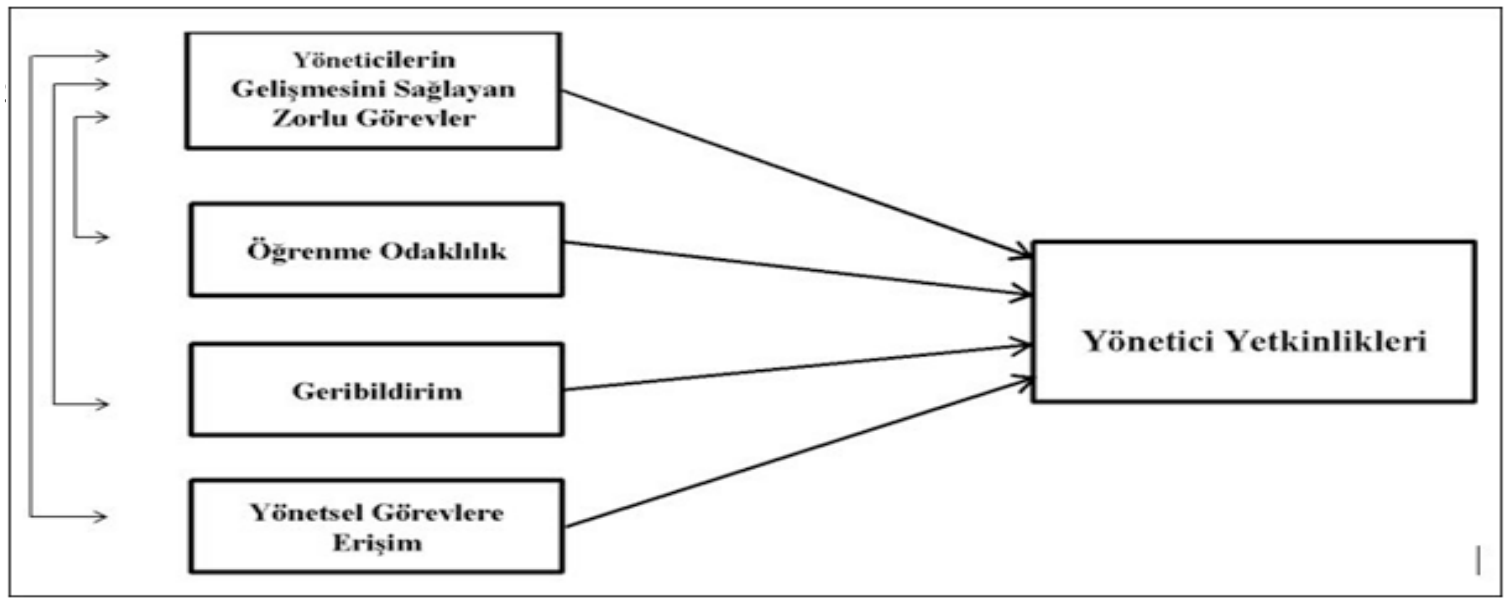

\subsection{Araştırmanın Modeli ve Değişkenleri}

Araştırmanın kavramsal modelinde yöneticilerin gelişimini arttıran zorlu görevler, öğrenme odaklılık, geri bildirim alma ve zorlu görevlere erişim bağımsı değişkenler olup yönetici yetkinlikleri üzerinde pozitif bir etkiye sahip olduğu ileri sürülmektedir (Dragoni vd., 2009; DeRue, 2009; McCauley, 2001; McCall vd., 2002). Aynı zamanda bağımsız değişkenler arasında ilişki incelenmiş ve yönetici yetkinlikleri alt boyutları demografik değişkenlere göre de test edilmiştir.

\subsubsection{Yönetici Yetkinlikleri Ölçeği}

Yönetici yetkinlikleri (end-stateskills/managerial competencies) yöneticilerin kariyerleri boyunca terfiler ve edindikleri tecrübeler sonucunda kazandıkları yönetim becerilerinin tümüdür (Lesliev.d., 2002). Yönetici yetkinlikleri kavramı 3 boyutta da incelenmektedir. Bunlar; genel yetenek (Busineess Knowledge), girişimcilik (Negotiator) ve yenilikçilik (Innovator) olarak kavramsallaştırılmaktadır (Leslievd., 2002: 82). Genel yetenek boyutu iş bilgisi boyutunu da içeren bir boyuttur. Bu kavramı iki boyut yerine tek bir kavramla anlatmanın doğru olduğu belirten (Spreitzer vd., 1997) yeni yapılacak olan çalışmalarda tek boyut olarak kullanılabileceğini belirtmişlerdir. Girişimcilik kavramı, kişilerarası beceri ve bağlıık kavramlarının tek bir boyut olarak isimlendirilmesidir. İçerik olarak konuları aynıdır. Yenilikçilik boyutu da cesaret ve kültürlerarası boyutu kapsamaktadır.

\subsubsection{Zorlu Görevlere Erişim Ölçeği}

Zorlu görevlere erişim, yöneticilerin kişisel gelişimini sağlayan iş fırsatlarını elde etme isteği olarak tanımlanabilir. Zorlu görevlere erişim ölçeği Dragoni vd. (2009) tarafından geliştirilmiş olup üç ifadeden oluşmaktadır. Bu ifadeler: (1) "Yeni bilgi ve becerileri öğrenmeyi gerektiren işlerde/görevlerde çalışma imkânım oldu", (2) "Bu şirkette çalışırken gelişmemi sağlayacak zorlu görevler/işlerde çalıştım”, (3) "Bu işletmede çalışmaya başladığımdan beri birçok zorlu ve fırsatlarla dolu görevlerde çalışma şansı yakaladım” şeklindedir.

\subsection{3.Öğrenme Odaklılık Ölçeği}

Öğrenme odaklılık, örgütün öğrenmek istediği tüm bilgileri veya ihtiyaç duyduğu değişimi elde etmek ve sürekli değişen dış çevreye uyum sağlayabilmek için işletmelerin ve yöneticilerin kullandığı yöntemdir (Mavondovd., 2005: 1237). Vande Welle (1997) tarafından geliştirilen ölçek 5 maddeden oluşmaktadır. "Çok şey öğrenebileceğim gelişmemi sağlayacak zorlu görevleri tercih ederim" ve "Yeni yetenekler kazanabileceğim zor ve fırsatlarla dolu görevlerden hoşlanırım" gibi ifadelerden oluşmaktadır.

\subsubsection{Geri Bildirim Alma Ölçeği}

Geri bildirim, iş tanımında ve iş analizinde saptanan standartlara ne ölçüde yaklaşıldığı konusunda bireylere bilgiler vermektir (Maitland, 1998: 70). Geri bildirim alma ölçeği Morgeson ve Humphrey (2006) tarafından geliştirilen 6 maddeden oluşan bir ölçektir. Örnek olarak, "Işsimde gerçekleştirdiğim görevler performansımı 
değerlendirmem için bana bilgi sağlamış olur" ve "iş̧imde yaptıklarım performansım hakkında bana geri bildirim sağlamış olur" gibi ifadeler sorulmuştur. Geri bildirim aslında farklı kanallardan karşımıza çıkabilir: örneğin: işin kendisi bize performansımı hakkında bilgi verebilir, yöneticiler tarafından verilen geri bildirimler ve en hızı şekilde aldığımız çalışma arkadaşları tarafından verilen geri bildirim gibi.

\subsubsection{Yöneticilere Verilen Gelişmelerine Yönelik Zorlu Görevler Ölçeği ve Boyutları}

Yukarıdaki Tablo 1'de sunulan 15 boyutun niceliksel olarak fazla olması sebebiyle yapılan yeni çalışmada 5 boyutun diğer 10 boyut altında toplandığı görülmüştür (DeRue ve Welman, 2009). Bu boyutlar dikkate alınarak inceleme yapıldığında; zorlu görevleri az olan yöneticilerin diğer yöneticilere göre daha az gelişim gösterdiği ve zorlu görevi çok olan yöneticilerin ise gelişimsel durumunun daha kaliteli ve işletmeye daha faydalı olduğu yönündedir. Genelde zorlu görevlerin boyutlarından bir tanesinin bile güncel ve yenilikçi olması diğer boyutların da aynı şekilde seyretmesine neden olmaktadır (McCauley,1999). McCauley ve diğerlerinin (1999) geliştirmiş olduğu Gelişmeye Yönelik Zorlu Görevler Ölçeği (Developmental Challenge Profile) 50 madde ve 10 boyuttan oluşmaktadır. Bu boyutlar; 1) alışılmadık sorumluluklar, 2) örgüte yeni yön verme, 3) önceden çözülemeyen problemler, 4) çalışanlarla olan problemler, 5) zor şartlarda karar verme, 6) yönetim alanı genişliği, 7) üst yönetimi etkileyebilme, 8) dış baskıyla başa çıkabilme, 9) kültürlerarası çalışabilme ve 10) işgücü çeşitliliğini yönetmedir (DeRue ve Welman, 2009).

Yöneticinin üstlendiği bir görevin, gelişmesini sağlayacak bir görev olup olmadığını anlamak için belirli koşullar gerekebilir. Bu koşulların sağlanmasında bu 10 boyut önem taşımaktadır. Her bir görev her boyutun içeriğini taşımayabilir ancak bir boyutun bile özelliğini taşıması bu görevin yönetici için gelişimsel ve zorlu bir görev olduğunu göstermektedir (Lawvd., 1998). 1998 yııında yapılan çalışmada 10 boyuttan oluşan anket sorularının uzun olacağı düşünülmüş ve bu nedenle de ölçeğin daha kolay kullanılabilmesi için (De Rue ve Wellman, 2009) 25 soru ve 5 boyuta indirgenmiştir. Bu boyutlar; alışılmadık sorumluluklar, zor şartlarda karar verme, örgüte yeni yön verme, işgücü çeşitliliği ve kültürlerarası çalışmadır (DeRue vd., 2009: 865).

\subsection{Araştırmanın Hipotezleri}

Araştırmanın modeline göre; yöneticilere gelişimini artııran zorlu görevler verilmesi, öğrenme odaklıık, yöneticilerin geri bildirim almaları ve yönetsel görevlere erişim gibi faktörler yönetici yetkinliklerini arttırmaktadır. Aynı zamanda bağımsız değişkenler arasında da ilişki varsayılmaktadır. Buradan hareketle aşağıdaki hipotezler oluşturulmuştur.

Hipotez 1. Zorlu görevlerin yöneticilik yetkinlikleri üzerinde etkisi vardır.

Hipotez 2. Öğrenme odaklılığın yönetici yetkinlikleri üzerinde etkisi vardır.

Hipotez 3. Geri bildirim almanın yönetici yetkinlikleri üzerinde etkisi vardır.

Hipotez 4. Zorlu görevlere erişimin yönetici yetkinlikleri üzerinde etkisi vardır.

Düşük öğrenme odaklılık düzeyine sahip bireyler görevleri zorlu bulma eğilimindedirler; çünkü gelişimsel görevlendirmeler yeterince gelişmemiş becerilerin kullanılmasını gerektirmektedir (McCauley vd., 1999). Dolayısıyla da yüksek öğrenme odakıı bireyler bu tip görevleri yerine getirme konusunda isteklidirler. Bu bireyler sahip oldukları üstün özellikleri sergileyebilecekleri görevlere yönelirler. Diğer taraftan yüksek öğrenme odaklı bireyler gelişmelerine yönelik zorlu görevleri kabul edebilirler, zira bu görevleri var olan yeteneklerini ortaya çıkarma fırsatı olarak görebilirler.

Alt düzey yöneticinin öğrenme odaklılığı ile görevlendirildiği zorlu görevler arasındaki ilişkinin pozitif olması beklenmesine karşın; bu ilişkinin gücü becerilerini geliştirme konusunda motive olan yöneticilerin gelişmelerini arttıran zorlu görevlere erişim derecelerine göre değişebilmektedir. Burada erişim, yöneticilerin gelişimini arttıran zorlu görevleri güvence altına almak için algılanan bir fırsat olarak tanımlanmaktadır. Erişim birey davranışını zorlaştıran ya da kolaylaştıran sosyal bir yapıdır ve önceki araştırmalarda, yöneticilerin zorlu görevlere erişimlerinin farklılık gösterdiği ortaya konmuştur (Campion vd., 1994). 
Yüksek öğrenme odaklılığa sahip olmak motive olsalar dahi yöneticilerin bu tip görevleri elde etmek için baskı kurması beklenmektedir. Bunun tersine, yöneticiler gelişimsel görevlendirmelere erişim elde ettiklerinde bu yöneticilerin güçlü olan öğrenme odaklılıkları desteklenmiş olacaktır ve aktif olarak gelişimsel görevlendirmeleri takip etmeleri ve bu görevler içinde yer almaları daha kolay hale gelecektir. Buradan hareketle;

Demografik değişkenlere göre yönetici yetkinlikleri alt boyutlarında farkılıı olup olmadığını test etmek için kurulan hipotezler de aşağıda yer almaktadır;

Hipotez 5. Yönetici yetkinlikleri ölçeği ve alt boyutları ile cinsiyete göre farklılık göstermektedir.

Hipotez 6. Yönetici yetkinlikleri ölçeği ve alt boyutları eğitim duruma göre farklılık göstermektedir.

Hipotez 7. Yöneticilik yetkinlikleri ölçeğinden ve alt boyutlardan elde edilen ortalama puanları faaliyet sektörüne göre farklılık göstermektedir.

\section{4. Örneklem}

Araştırmanın evreni, Manisa Organize Sanayi Bölgesinde faaliyet göstermekte olan kayıtlı 173 firmada çalışan genel müdür (veya yardımcıları) ve bölüm yöneticilerinden oluşmaktadır. Araştırmanın örneklemi ise 30 firmanın 3 farklı birimindeki 230 orta düzey yönetici (örnek: insan kaynaklarından sorumlu yönetici veya insan kaynakları müdürü; finans müdürü veya finanstan sorumlu birim yöneticisi; en az 3 bölüm yöneticisinden ve orta düzey yöneticisinden) ve onların amirlerinden 53 üst düzey yöneticiden oluşmaktadır.

Araştırmada kolayda örnekleme tekniği kullanılmışır. Uygulama öncesinde üst düzey yöneticilere ve orta düzey yöneticilere çalışma ile ilgili bilgi verilmiş olup analizlerin tümünde SPSS 20 (Statistical Package for Social Sciences) paket programından yararlanılmıştır.

\section{5.ölçeklerin Geçerliliği ve Güvenilirliği}

Araştırmada, ölçeklerin geçerliliğini tespit etmek amacıyla keşfedici faktör analizi kullanılmış ve ilgili analizin uygunluğunu test etmek için de KMO Örnekleme Uygunluğu Ölçümü (Kaiser-Meyer-Olkin Measure of Sampling Adequacy) ile Bartlett's Testi (Bartlett's Test of Sphericity) uygulanmıştır.

Literatür incelendiğinde birçok araştırmada yapıldığı üzere toplanan verilerin her bir değişkeninin boyutlarını görmek için ve ölçek maddelerinin faktörlerle ilişkisini ortaya çıkarmak amacıyla temel bileşenler yöntemi varimaxa dönüştürülmektedir. Buna göre değişkenlerin her birine (yönetici yetkinlikleri; yöneticilere verilen zorlu görevler, öğrenme odaklılık, geri bildirim alma, gelişimsel özelliğe sahip zorlu görevlere erişim) ayrı ayrı faktör analizi yapılmıştır. 
Yapılan analiz sonucunda örneklem büyüklüğünü test etmek amacıyla Kaiser-Meyer-Olkin (KMO) testi uygulanmıştır. KMO değeri 0,690 olduğu belirlenmiştir. Faktör analizi yapmak için yeterli olduğu sonucuna ulaşılmıştır (Çokluk ve ark., 2012:207). Birinci faktörün Cronbach’s Alpha güvenirlilik katsayısı 0,865, ikinci faktörün 0,841, üçüncü faktörün ise 0,798 olarak bulunmuştur. Ölçeğin ve alt boyutlarının yeterli güvenilirlikte olduğu tespit edilmiştir. Analize temel olarak 22 madde için öz değeri 1'in üzerinde olan üç boyut olduğu görülmüştür. Bu boyutların toplam varyansa yaptıkları katkı \%52,124'dır. Üç faktör için tekrarlanan analizde, faktörlerin toplam varyansa yaptıkları katkının birinci faktör olan "girişimcilik" için \%18,831; ikinci faktör olan "yenilikçilik" için \%17,23; üçüncü faktör olan "genel yetenek" için \%16,055 olduğu tespit edilmiştir.

Tablo 5: Yöneticilerin Gelişmesine Yönelik Verilen Zorlu Görevler Ölçeği Açıklayıcı Faktör Analizi

\begin{tabular}{|c|c|c|c|}
\hline Faktörler ve maddeler & $\begin{array}{l}\text { Faktör } \\
\text { Yükü }\end{array}$ & $\begin{array}{l}\text { Öz Değer } \\
(\Lambda)\end{array}$ & $\begin{array}{l}\text { Açıklanan } \\
\text { Varyans (\%) }\end{array}$ \\
\hline \multicolumn{4}{|l|}{ F1: Dış baskı ile başa çıkabilme $(\alpha=0,743)$} \\
\hline $\begin{array}{l}\text { 30.Farklı cinsiyetten ve etnik gruplara mensup çalışanlardan yöneticiler } \\
\text { yetiştirmekteyim }\end{array}$ & 0,816 & \multirow{6}{*}{5,032} & \multirow{6}{*}{15,159} \\
\hline 36.Birçok farklı birim ve ekiplerden sorumluyum & 0,768 & & \\
\hline $\begin{array}{l}\text { 48.İşiniz diğer örgütsel birim veya bölümler ile yoğun bir koordinasyon } \\
\text { gerektirmektedir }\end{array}$ & 0,696 & & \\
\hline $\begin{array}{l}\text { 8.Doğrudan yönetme yetkisine sahip olmadığım farklı iş birimlerini koordine } \\
\text { etmem gerekmektedir }\end{array}$ & 0,661 & & \\
\hline 35.Önemli hedeflerinizi gerçekleştirmek için zaman kısıtınız bulunmaktadır. & 0,638 & & \\
\hline $\begin{array}{l}\text { 6.Şu anki pozisyonumda benim yönetim fonksiyonlarım ve sorumluluklarım } \\
\text { artmıştır. }\end{array}$ & 0,624 & & \\
\hline \multicolumn{4}{|l|}{ F2: Yönetim alanı Genişliği $(\alpha=0,745)$} \\
\hline $\begin{array}{l}\text { 19.İ̧̧iniz (zaman zaman) farklı bir kültüre sahip yabancı bir ülkede çalışmanızı } \\
\text { gerektirmektedir. }\end{array}$ & 0,824 & \multirow{4}{*}{3,026} & \multirow{4}{*}{12,153} \\
\hline 9.İşim gereği farklı ülkelerdeki kişilerle iş bağlantısı yaparım. & 0,798 & & \\
\hline 20.Farklı özelliklere sahip bir çalışma grubunun parçasıyım & 0,715 & & \\
\hline $\begin{array}{l}\text { 49.İşimde, farklı kültürlerden gelen insanların geleneklerini ve değerlerini anlamak } \\
\text { zorundayım. }\end{array}$ & 0,668 & & \\
\hline \multicolumn{4}{|l|}{ F3: Üst yönetimi etkileme $(\alpha=0,704)$} \\
\hline $\begin{array}{l}\text { 13.Biriminizin güvenirliğini tüm işletmede yeniden tesis etmek ihtiyacını } \\
\text { duymaktasınız. }\end{array}$ & 0,757 & \multirow{5}{*}{2,23} & \multirow{5}{*}{11,639} \\
\hline 43.Benden önceki yöneticilerin yarattğı büyük problemleri çözerim. & 0,714 & & \\
\hline $\begin{array}{l}\text { 18.Önemli hedeflerinize ulaşmak için, diğer birim veya bölümlerde aynı seviyede } \\
\text { bulunduğunuz yöneticileri etkilemeniz gerekmektedir }\end{array}$ & 0,713 & & \\
\hline $\begin{array}{l}\text { 29.İ̧sim, işletmemiz üzerinde önemli etkiye sahip yabancı firmalar, aracılar ve } \\
\text { devletler ile ilişkileri yönetmeyi de içermektedir. }\end{array}$ & 0,661 & & \\
\hline 7.Çalışttğım müşteri grupları (portföyü) çok çeşitlidir. & 0,567 & & \\
\hline \multicolumn{4}{|l|}{ F4: İş gücü çeşitliliğini yönetme $(\alpha=0,783)$} \\
\hline 45.İşimi çabuk tamamlamam için çoğu zaman üzerimde baskı vardı & 0,710 & \multirow{6}{*}{2,14} & \multirow{6}{*}{10,787} \\
\hline 46.İşinizde sürekli baskı altındasınız, nefes alacak zamanınız bulunmamaktadır & 0,688 & & \\
\hline $\begin{array}{l}\text { 38. Hedeflerinizi başarmak için bağlı olduğunuz amirinizin üstündeki yöneticileri } \\
\text { etkilemeli ve onlarla birlikte çalışmalısınız. }\end{array}$ & 0,627 & & \\
\hline $\begin{array}{l}\text { 47.Sendikalarla, müşterilerle ya da ortaklarınızla, düzenli olarak görüşme/pazarlık } \\
\text { yapmak zorundasınız. }\end{array}$ & 0,617 & & \\
\hline 16.Mevcut işim tecrübeli bir yöneticinin bile başa çıkabileceğinden daha zordur. & 0,570 & & \\
\hline 4.Astlarınız aldığınız kararlarınızın uygulanmasına karşı çıkarlar. & 0,409 & & \\
\hline F5: Zor şartlarda karar verme $(\alpha=0,680)$ & & & \\
\hline
\end{tabular}




\begin{tabular}{|c|c|c|c|}
\hline $\begin{array}{l}\text { 17.Önemli hedeflerinize ulaşmak için, işletme dışındaki kişi ve kurumları } \\
\text { etkilemeniz gerekmektedir (örn. Müşteriler, tedarikçiler, sendikalar, resmi } \\
\text { kurumlar) }\end{array}$ & 0,762 & \multirow{3}{*}{1,63} & \multirow{3}{*}{8,910} \\
\hline $\begin{array}{l}\text { 27.İ̧̧imin bir parçası olarak devlet yetkilileri ya da kurumları ile ilişkileri } \\
\text { yönetiyorum. }\end{array}$ & 0,750 & & \\
\hline 26.Birçok farklı ürün, teknoloji ve hizmetin sağlanmasında sorumluluğa sahipsiniz. & 0,629 & & \\
\hline \multicolumn{4}{|c|}{ Toplam $(\alpha=0,761) \quad$ Toplam Açıklanan varyans $=58,649$} \\
\hline \multicolumn{4}{|l|}{$\mathrm{KMO}=0,754 ; \times 2(276)=2184,199 ;$} \\
\hline \multicolumn{4}{|l|}{ Bartlett Küresellik Testi $(p)=0,000$} \\
\hline
\end{tabular}

Yapılan analiz sonucunda örneklem büyüklüğünü test etmek amacıyla Kaiser-Meyer-Olkin (KMO) testi uygulanmıştır. KMO değeri 0,754 olduğu belirlenmiştir. Faktör analizi yapmak için yeterli olduğu sonucuna ulaşılmıştır (Çokluk ve ark., 2012:207). Birinci faktörün Cronbach's Alpha güvenirlilik katsayısı 0,743, ikinci faktörün 0,745 , üçüncü faktörün ise 0,704 , dördüncü faktör 0,783 ve beşinci faktör 0,680 olarak bulunmuştur. Ölçeğin ve alt boyutlarının yeterli güvenilirlikte olduğu tespit edilmiştir. Analize temel olarak 24 madde için öz değeri 1'in üzerinde olan beş boyut olduğu görülmüştür. Bu boyutların toplam varyansa yaptıkları katkı \%58,649'dur. Beş faktör için tekrarlanan analizde, faktörlerin toplam varyansa yaptıkları katkının birinci faktör olan "dış baskı ile başa çıkabilme" için \%15.2; ikinci faktör olan "yönetim alanı genişliği" için \%12,153; üçüncü faktör olan "üst yönetimi etkileyebilme" için \%11,639; dördüncü faktör olan "işgücü çeşitliliğini yönetme" için \%10,787; beşinci faktör olan "zor şartlarda karar verme" için \%8.910 olduğu tespit edilmiştir.

Tablo 6: Öğrenme Odaklılık Düzeyine İlişkin Açıklayıcı Faktör Analizi Sonuçları

\begin{tabular}{|c|c|c|c|}
\hline Faktörler ve Maddeler & Faktör Yükü & Öz Değer $(\Lambda)$ & $\begin{array}{l}\text { Açıklanan } \\
\text { Varyans }\end{array}$ \\
\hline \multicolumn{4}{|l|}{ Öğrenme Odaklılık $(\alpha=0,906)$} \\
\hline $\begin{array}{l}\text { Çok şey öğrenebileceğim gelişmemi sağlayacak zorlu } \\
\text { görevleri tercih ederim }\end{array}$ & 0,896 & \multirow{5}{*}{3,782} & \multirow{5}{*}{75,649} \\
\hline $\begin{array}{l}\text { İşimde yeni yetenek ve bilgiler edinebileceğim fırsatları } \\
\text { ararım }\end{array}$ & 0,868 & & \\
\hline $\begin{array}{l}\text { Yeni yetenekler kazanabileceğim zor ve firsatlarla dolu } \\
\text { görevlerden hoşlanırım }\end{array}$ & 0,910 & & \\
\hline $\begin{array}{l}\text { Yeteneklerimi geliştirmek, benim için risk almaya değer } \\
\text { bir öneme sahiptir }\end{array}$ & 0,860 & & \\
\hline $\begin{array}{l}\text { Yüksek yetenek ve kabiliyet gerektiren işlerde çalışmayı } \\
\text { tercih ederim }\end{array}$ & 0,864 & & \\
\hline \multicolumn{4}{|l|}{ Toplam Açıklanan varyans=75,649 } \\
\hline \multicolumn{4}{|l|}{$\mathrm{KMO}=0,850$} \\
\hline \multicolumn{4}{|l|}{$\chi 2(10)=855,926$} \\
\hline Bartlett Küresellik Testi $(p)=0,000$ & & & \\
\hline
\end{tabular}

Analiz sonucunda KMO değerinin 0,850 olduğu belirlenmiştir. Bu bulgu doğrultusunda, örneklem yeterliliğinin faktör analizi yapmak için “iyi derecede yeterli” olduğu sonucuna ulaşılmıştır. Ayrıca Bartlett küresellik testi sonuçları incelendiğinde, elde edilen ki kare değerinin anlamlı olduğu görülmüştür $(\chi 2(10)=855,926 ; p<0,01)$. Bu doğrultuda, verilerin çok değişkenli normal dağılımdan geldiği kabul edilmiştir. Bu çerçevede, tanımlanan bir faktörün, toplam varyansa yaptığı katkının yeterli olduğu görülmektedir. Tabloda görüldüğü üzere "Öğrenme Odaklılık" varyansın \%75,649'unu açıklamaktadır. 
Tablo 7: Gelişim Özeliğine Sahip Zorlu Görevlere Erişim Düzeyine İlişkin Faktör Analizi

\begin{tabular}{|c|c|c|c|}
\hline Faktörler ve Maddeler & Faktör Yükü & Öz Değer $(\Lambda)$ & $\begin{array}{l}\text { Açıklanan } \\
\text { Varyans }\end{array}$ \\
\hline \multicolumn{4}{|c|}{ Gelişim Özelliğine Sahip Zorlu Görevlere Erişim $(\alpha=0,884)$} \\
\hline $\begin{array}{l}\text { Yeni bilgi becerileri öğrenmeyi } \\
\text { gerektiren işlerde/görevlerde çalışma } \\
\text { imkanım oldu }\end{array}$ & 0,836 & \multirow{3}{*}{2,442} & \multirow{3}{*}{81,413} \\
\hline $\begin{array}{l}\text { Bu şirkette çalışırken gelişimimi } \\
\text { sağlayacak zor işlerde/görevlerde } \\
\text { çalıştım }\end{array}$ & 0,931 & & \\
\hline $\begin{array}{l}\text { Bu işletmelerde çalışmaya } \\
\text { başladığımdan beri birçok zorlu ve } \\
\text { firsatlarla dolu görevlerde çalışma } \\
\text { şansı yakaladım }\end{array}$ & 0,936 & & \\
\hline \multicolumn{4}{|l|}{ Toplam Açıklanan varyans $=81,413$} \\
\hline \multicolumn{4}{|l|}{$\mathrm{KMO}=0,701 ;$} \\
\hline \multicolumn{4}{|l|}{$\chi 2(10)=446,607$} \\
\hline Bartlett Küresellik Testi $(p)=0,000$ & & & \\
\hline
\end{tabular}

Analiz sonucunda KMO değerinin 0,701 olduğu belirlenmiştir. Bu çerçevede, tanımlanan bir faktörün, toplam varyansa yaptığı katkının yeterli olduğu görülmektedir. Tabloda görüldüğü üzere "Gelişim Özeliğine Sahip Zorlu Görevlere Erişim" varyansın \%81,413'ünü açıklamaktadır. Anket formunda yer alan katılımcıların gelişim özeliğine sahip zorlu görevlere erişim $(0,884)$ güvenilirliğe sahip olduğu tespit edilmiştir.

Tablo 8: Geri Bildirim Düzeyine İlişkin Faktör Analizi

\begin{tabular}{|c|c|c|c|}
\hline Faktörler ve Maddeler & Faktör Yükü & Öz Değer $(\Lambda)$ & $\begin{array}{l}\text { Açıklanan } \\
\text { Varyans }\end{array}$ \\
\hline \multicolumn{4}{|l|}{ Geri Bildirim Alma $(\alpha=0,884)$} \\
\hline $\begin{array}{l}\text { İşimde yaptığım faaliyetler niteliksel olarak performansımın } \\
\text { etkinliğini açıkça ortaya koyar }\end{array}$ & 0,827 & \multirow{6}{*}{4,552} & \multirow{6}{*}{75,873} \\
\hline $\begin{array}{l}\text { İşimde yaptıklarım performansım hakkında bana geri bildirim } \\
\text { sağlamış olur }\end{array}$ & 0,881 & & \\
\hline $\begin{array}{l}\text { İşimde gerçekleştirdiğim görevler performansımı } \\
\text { değerlendirdiğim için bana bildi sağlamış olur }\end{array}$ & 0,878 & & \\
\hline $\begin{array}{l}\text { Yöneticilerim ve çalışma arkadaşlarımdan iş performansım } \\
\text { hakkında oldukça geri bildirim alırım }\end{array}$ & 0,883 & & \\
\hline $\begin{array}{l}\text { Yönetici ve çalışma arkadaşlarım niteliksel ve niceliksel olarak } \\
\text { performansımın etkinliği konusunda geri bildirim sağlar }\end{array}$ & 0,897 & & \\
\hline $\begin{array}{l}\text { Örgütte diğer çalışanlar ve yöneticilerden performansım } \\
\text { hakkında geri bildirim alırım }\end{array}$ & 0,858 & & \\
\hline \multicolumn{4}{|l|}{ Toplam Açıklanan varyans $=75,873$} \\
\hline \multicolumn{4}{|l|}{$\mathrm{KMO}=0,852$} \\
\hline \multicolumn{4}{|l|}{$\chi 2(10)=1375,137$} \\
\hline Bartlett Küresellik Testi $(p)=0,000$ & & & \\
\hline
\end{tabular}

Analiz sonucunda KMO değerinin 0,852 olduğu belirlenmiştir. Bu bulgu doğrultusunda, örneklem yeterliliğinin faktör analizi yapmak için "iyi derecede yeterli" olduğu sonucuna ulaşılmıştır. Bu çerçevede, tanımlanan bir 
faktörün, toplam varyansa yaptığı katkının yeterli olduğu görülmektedir. Tabloda görüldüğü üzere "Geri Bildirim Alma" varyansın \%75,873'ünü açıklamaktadır. Anket formunda yer alan katılımcıların geri bildirim alma $(0,930)$ güvenilirliğe sahip olduğu tespit edilmiştir.

\subsection{Korelasyon ve Regresyon Analizleri}

Değişkenler arasında birebir ilişkileri açıklamak amacıyla korelasyon analizi yapılmıştır. Tablo 9'da görüldüğü üzere her bir sürekli değişkenin birbiriyle ilişkisi hesaplanmıştır.

Tablo 9: Korelasyon Analizi

\begin{tabular}{|c|c|c|c|c|c|c|c|c|c|c|c|}
\hline Değişkenler & 1 & 2 & 3 & 4 & 5 & 6 & 7 & 8 & 9 & 10 & 11 \\
\hline DBÇ & 1 & ,057 &, $245^{* *}$ & ,086 &, $197^{* *}$ & 105 & ,155** & ,097 & ,206** & 0,74 & ,024 \\
\hline YAG & ,057 & 1 &, $205 * *$ &, $261 * *$ &, $185 * *$ & ,058 &, $151 *$ & ,159* &, $237 * *$ &,- 069 & ,125 \\
\hline ÜYE &, $245^{* *}$ & ,205** & 1 &, $193 * *$ & ,395** &, $259 * *$ & ,283** & ,291** & ,299** & ,090 & ,161* \\
\hline İ̧̧Y & ,086 &, $261 * *$ &, $193 * *$ & 1 & ,082 &,- 096 & ,014 & ,138* &, $334 * *$ & ,016 & ,0331 \\
\hline ZKV &, $197^{* *}$ &, $185^{* *}$ &, $395 * *$ & ,082 & 1 & ,168* & ,273** & ,264** & ,160* &, 046 &, $197^{* *}$ \\
\hline ÖO & 105 & ,058 &, $259 * *$ & ,096 & ,168* & 1 &, $460 * *$ &, $484 * *$ & ,072 & 106 &, $163^{*}$ \\
\hline GÖS & ,155*, & ,151* &, $283 * *$ & ,014 & ,273** &, $460 * *$ & 1 & ,668** & ,173** & ,088 & 106 \\
\hline GBA & ,097 & ,159* & ,291** & ,138* &, $264 * *$ &, $484^{* *}$ & ,668** & 1 & ,065 &, 000 & ,061 \\
\hline GB &, $206 * *$ &, $237 * *$ & ,299** &, $334 * *$ & ,160* & ,072 & ,173** & ,065 & 1 & $-0,09$ &, $182^{* *}$ \\
\hline YB & ,074 &,- 069 & ,090 & ,016 &,- 046 & 106 & ,088 & ,000 &,- 009 & 1 & ,087 \\
\hline GYB &,- 024 & 125 &, $161^{*}$ & ,031 &, $197 * *$ &, $163^{*}$ & 106 & ,061 &, $182 *$ & ,087 & 1 \\
\hline
\end{tabular}

DBÇ=Dış baskı ile başa çıkabilme YAG=Yönetim alanı genişliği ÜYE=Üst yönetimi etkileme içY=işgücü çeşitliliğini yönetme ZKV=Zor şartlarda karar verebilme ÖO=Öğrenme odaklılık GÖS=Gelişim özelliğine sahip zorlu görevlere erişim GBA=Geri bildirim alma GB=Girişimcilik boyutu YB=Yenilikçilik boyutu GTY=Genel yetenek boyutu

Çoklu değişkenler arasındaki ilişkileri incelemek amacıyla regresyon analizi yapılmıştır. Yapılan regresyon analizinde Tablo 8'de sunulan Beta değerleri bağımsız değişkenin bağımlı değişkenlerle olan ilişkilerinde göreceli önemlerini göstermektedir. Bunun yanı sıra p- değerleri değişkenlerin anlamlılık düzeylerini göstermektedir.

Tablo 10: Yöneticilerin Gelişmesine Yönelik Verilen Zorlu Görevlerin Alt Boyutları ve Öğrenme Odaklılık, Geri Bildirim Alma ve Gelişim Özelliğine Sahip Zorlu Görevlere Erişimin Yönetici Yetkinlikleri Girişimcilik Alt Boyutu Üzerindeki Etkisi

\begin{tabular}{|c|c|c|c|c|c|c|c|}
\hline $\begin{array}{l}\text { Bağımlı } \\
\text { Değişken }\end{array}$ & Bağımsız Değişken & Beta & t değeri & $p$ değeri & R-square (düzeltlm) & F değişkeni & Anlamlılık \\
\hline \multirow{9}{*}{ Girişimcilik } & DBÇ & 128 & 2,052 & ,041 & \multirow{5}{*}{$198(, 181)$} & \multirow{5}{*}{11,089} & \multirow{5}{*}{,000 } \\
\hline & YAG & 122 & 1,935 & ,054 & & & \\
\hline & ÜYE & 187 & 2,764 & ,006 & & & \\
\hline & iç̧Y & ,253 & 4,036 & ,000 & & & \\
\hline & ZKV & 018 & 267 & 790 & & & \\
\hline & Öğrenme Odaklılık & ,043 & 339 & 691 & \multirow{3}{*}{ 199(,174) } & \multirow{3}{*}{0,93} & \multirow{3}{*}{ 911 } \\
\hline & & & & & & & \\
\hline & Geri bildirim Alma & 030 &,- 019 & ,985 & & & \\
\hline & $\begin{array}{c}\text { Zorlu Görevlere } \\
\text { Erişim }\end{array}$ & ,037 & 1,513 & 132 & ,207(,179) & 2,289 & 132 \\
\hline
\end{tabular}

(DBÇ=Dış baskı ile başa çıkabilme YAG=Yönetim alanı genişliği ÜYE=Üst yönetimi etkileme içY=işgücü çeşitliliğini yönetme ZKV=Zor şartlarda karar verebilme) 
Tablo 9'da izlenebileceği gibi, dış baskı ile başa çıkabilme boyutu (Beta=,128, t=2,052, p=,041), üst yönetimi etkileyebilme boyutu (Beta=,187, $t=2,764, p=, 006$ ) ve iş gücü çeşitliliğini yönetme boyutu (Beta=,253, t=4,036, $p=, 000$ ) girişimcilik üzerinde $\% 2$ oranında açıklayıcı olmuştur. Dragoni vd. (2009) çalışmasında da yöneticilere verilen zorlu görevlerin yönetici yetkinlikleri üzerinde etkili unsurlar olduğu belirtilmektedir.

Tablo 11: Yöneticilerin Gelişmesine Yönelik Verilen Zorlu Görevlerin Alt Boyutları ve Öğrenme Odaklılık, Geri Bildirim Alma ve Gelişim Özelliğine Sahip Zorlu Görevlere Erişimin Yönetici Yetkinlikleri Yenilikçilik Alt Boyutu Üzerindeki Etkisi

\begin{tabular}{|c|c|c|c|c|c|c|c|}
\hline $\begin{array}{l}\text { Bağımlı } \\
\text { Değişken }\end{array}$ & Bağımsız Değişken & Beta & $\mathrm{t}$ değeri & $\mathrm{p}$ değeri & $\begin{array}{l}\text { R-square } \\
\text { (düzeltIm) }\end{array}$ & F değişkeni & Anlamlılık \\
\hline \multirow{9}{*}{ Yenilikçilik } & DBÇ &,- 084 & $-1,252$ & 212 & \multirow{5}{*}{,060(,039) } & \multirow{5}{*}{2,855} & \multirow{5}{*}{,016 } \\
\hline & YAG & ,804 & 1,220 & 224 & & & \\
\hline & ÜYE & 105 & 1,441 & 151 & & & \\
\hline & İ̧̧Y &,- 017 &,- 248 & ,085 & & & \\
\hline & ZKV & 158 & 2,205 & ,031 & & & \\
\hline & Öğrenme Odaklılık & 162 & 2,166 & ,031 & & & \\
\hline & & & & & ,080(,048) & 2,398 & ,093 \\
\hline & Geri bildirim Alma &,- 093 & $-1,202$ & 231 & & & \\
\hline & Zorlu Görevlere Erişim & ,050 &, 552 &, 581 &, $081(, 048)$ & ,305 &, 581 \\
\hline
\end{tabular}

Tablo 10'a göre zor şartlarda karar verme boyutu (Beta=,158, t=2,205, $p=, 031$ ) yenilikçilik üzerinde \%6 oranında açıklayıcı olmuştur. Dragoni vd. (2009) çalışmasında da yöneticilere verilen zorlu görevlerin yönetici yetkinlikleri üzerinde etkili unsurlar olduğu tespit edilmiştir. Öğrenme odaklılık (Beta=,162, t=2,166, p=,031) yenilikçilik üzerinde $\% 8$ oranında açıklayıcı olmuştur.

Tablo 12: Yöneticilerin Gelişmesine Yönelik Verilen Zorlu Görevlerin Alt Boyutları ve Öğrenme Odaklılık, Geri Bildirim Alma ve Gelişim Özelliğine Sahip Zorlu Görevlere Erişimin Yönetici Yetkinlikleri Genel Yetenek Alt Boyutu Üzerindeki Etkisi

\begin{tabular}{|c|c|c|c|c|c|c|c|}
\hline $\begin{array}{l}\text { Bağımlı } \\
\text { Değişken }\end{array}$ & Bağımsız Değişken & Beta & t değeri & p değeri & $\begin{array}{l}\text { R-square } \\
\text { (düzeltlm) }\end{array}$ & F değişkeni & Anlamlılık \\
\hline \multirow{8}{*}{$\begin{array}{c}\text { Genel } \\
\text { yetenek }\end{array}$} & DBÇ & ,066 & 957 & 340 & \multirow{5}{*}{,027(,005) } & \multirow{5}{*}{1,229} & \multirow{5}{*}{ 297 } \\
\hline & YAG &,- 085 & $-1,226$ & 222 & & & \\
\hline & ÜYE & 126 & 1,687 & 093 & & & \\
\hline & İ̧̧ & ,016 & 2,235 & ,814 & & & \\
\hline & ZKV &,- 094 & $-1,294$ & 197 & & & \\
\hline & Öğrenme Odaklılık & 121 & 1,581 & 115 & \multirow{2}{*}{,038(,007) } & \multirow{2}{*}{1,250} & \multirow{2}{*}{ 288 } \\
\hline & Geri bildirim Alma &,- 055 &,- 696 & ,487 & & & \\
\hline & $\begin{array}{c}\text { Zorlu Görevlere } \\
\text { Erişim }\end{array}$ & ,037 & 1,427 & 155 & ,046(,012) & 2,037 & 155 \\
\hline
\end{tabular}

p değeri $p<.05$ olmadığında model anlamsızdır. Yöneticilere verilen zorlu görevlerin alt boyutlarının, yönetici yetkinlikleri alt boyutu olan genel yetenek üzerinde açıklayıcı bir etki tespit edilememiştir.

Yukarıdaki analizlerden hareketle Hipotez 1, 2, 3 ve 4’ün kabul olduğu söylenebilir. 
Demografik Değişkenlere Göre Yönetici Yetkinlikleri Alt Boyutlarına İlişkin Testler

Aşağıdaki tablolarda cinsiyet, eğitim durumu ve faaliyet sektörüne göre yönetici yetkinliklerinin farklılık gösterip göstermediği testleri yapılmıştır.

Tablo 13: Yönetici Yetkinlikleri Ölçeği ve Alt Boyutlardan Elde Edilen Ortalama Puanların Cinsiyete Göre Karşılaştırılması

\begin{tabular}{|c|c|c|c|c|c|c|}
\hline Değişken & Cinsiyet & $\mathrm{n}$ & & SS & $\mathrm{t}$ & $p$ \\
\hline \multirow{2}{*}{$\begin{array}{l}\text { Yönetici Yetkinlikleri } \\
\text { Ölçeği }\end{array}$} & Kadın & 89 & 3,87 & 0,46 & \multirow{2}{*}{$-2,900$} & \multirow{2}{*}{$0,004^{*}$} \\
\hline & Erkek & 141 & 4,08 & 0,42 & & \\
\hline \multirow{2}{*}{ Girişimcilik } & Kadın & 89 & 3,94 & 0,66 & \multirow{2}{*}{$-2,038$} & \multirow{2}{*}{$0,043^{*}$} \\
\hline & Erkek & 141 & 4,14 & 0,51 & & \\
\hline \multirow{2}{*}{ Yenilikçilik } & Kadın & 89 & 3,75 & 0,65 & \multirow{2}{*}{$-4,731$} & \multirow{2}{*}{$0,000 *$} \\
\hline & Erkek & 141 & 4,22 & 0,53 & & \\
\hline \multirow{2}{*}{ Genel yetenek } & Kadın & 89 & 3,92 & 0,53 & \multirow{2}{*}{0,223} & \multirow{2}{*}{0,824} \\
\hline & Erkek & 141 & 3,90 & 0,55 & & \\
\hline
\end{tabular}

Girişimcilik boyutu $(p=0,043)$ ile yenilikçilik $(p=0,000)$ boyutunun cinsiyete göre anlamlı bir farklılık gösterdiği tespit edilmiştir. Genel yetenek alt boyutundan elde edilen puanların ortalamasının cinsiyete göre istatistiksel olarak anlamlı bir farklılık göstermediği tespit edilmiştir. Medeni duruma göre bir farklılık tespit edilmediğinden tabloya yer verilmemiştir. "Yönetici yetkinlikleri ölçeği ve alt boyutları ile cinsiyete göre farklılık göstermektedir" şeklinde ifade edilen Hipotez 5 kabul edilmiştir.

Tablo 14: Yönetici Yetkinlikleri Ölçeği ve Alt Boyutlardan Elde Edilen Ortalama Puanların Eğitim Duruma Göre Karşılaştırılması

\begin{tabular}{|c|c|c|c|c|c|c|c|}
\hline Değişken & Eğitim durumu & $\mathrm{n}$ & $\underline{x}$ & SS & $F$ & $\mathrm{p}$ & $\begin{array}{c}\text { Gruplar } \\
\text { Arası Fark* }\end{array}$ \\
\hline \multirow{3}{*}{$\begin{array}{l}\text { Yönetici } \\
\text { Yetkinlikleri } \\
\text { Ölçeği }\end{array}$} & M.Yüksekokul(1) & 8 & 4,00 & 0,14 & \multirow{3}{*}{0,401} & \multirow{3}{*}{0,670} & \multirow{3}{*}{ - } \\
\hline & Üniversite (2) & 172 & 3,93 & 0,41 & & & \\
\hline & Yüksek Lisans (3) & 41 & 3,89 & 0,52 & & & \\
\hline \multirow{3}{*}{ Girişimcilik } & M.yüksekokul (1) & 8 & 4,00 & 0,30 & \multirow{3}{*}{0,090} & \multirow{3}{*}{0,914} & \\
\hline & Üniversite (2) & 172 & 4,00 & 0,63 & & & \\
\hline & Yüksek Lisans (3) & 41 & 3,96 & 0,67 & & & \\
\hline \multirow{3}{*}{ Yenilikçilik } & M.yüksekokul (1) & 8 & 4,35 & 0,38 & \multirow{3}{*}{3,368} & \multirow{3}{*}{$0,036^{*}$} & \multirow{3}{*}{$1>2 ; 1>3$} \\
\hline & Üniversite (2) & 172 & 3,89 & 0,58 & & & \\
\hline & Yüksek Lisans (3) & 41 & 3,77 & 0,74 & & & \\
\hline \multirow{3}{*}{$\begin{array}{c}\text { Genel } \\
\text { Yetenek }\end{array}$} & M.Yüksekokul(1) & 8 & 3,68 & 0,33 & \multirow{3}{*}{0,746} & \multirow{3}{*}{0,475} & \\
\hline & Üniversite (2) & 172 & 3,91 & 0,49 & & & \\
\hline & Yüksek Lisans (3) & 41 & 3,92 & 0,60 & & & \\
\hline
\end{tabular}

Yenilikçilik boyutu $(p=0,036)$ eğitim durumuna göre anlamlı bir farklılık gösterdiği tespit edilmiştir. Meslek yüksekokul mezunu kişilerin puan ortalaması üniversite ve yüksek lisans mezunu kişilerin puan ortalamasından daha yüksek olduğu tespit edilmiştir. Buradan hareketle "Yönetici yetkinlikleri ölçeği ve alt boyutları eğitim durumuna göre farklılık göstermektedir" şeklinde ifade edilen Hipotez 6 kısmen kabul edilmiştir. 
Tablo 15: Yöneticilik Yetkinlikleri Ölçeğinden ve Alt Boyutlardan Elde Edilen Ortalama Puanların Faaliyet Sektörüne Göre Karşılaştırılması

\begin{tabular}{|c|c|c|c|c|c|c|c|}
\hline Değişken & Sektör & $n$ & & SS & $\mathrm{F}$ & $p$ & Gruplar Arası Fark* \\
\hline \multirow{5}{*}{$\begin{array}{l}\text { Yönetici yetkinlikleri } \\
\text { ölçeği }\end{array}$} & Ambalaj (1) & 36 & 3,77 & 0,53 & \multirow{5}{*}{4,900} & \multirow{5}{*}{$0,001^{*}$} & \multirow{5}{*}{$\begin{array}{l}2>1 ; \\
2>5\end{array}$} \\
\hline & Gida (2) & 52 & 4,09 & 0,55 & & & \\
\hline & Otomotiv (3) & 20 & 4,00 & 0,18 & & & \\
\hline & \begin{tabular}{|l|} 
Elektronik (4) \\
\end{tabular} & 118 & 3,89 & 0,39 & & & \\
\hline & \begin{tabular}{|l|} 
İnşaat (5) \\
\end{tabular} & 4 & 3,34 & 0,09 & & & \\
\hline \multirow{5}{*}{ Girişimcilik } & Ambalaj (1) & 36 & 3,98 & 0,84 & \multirow{5}{*}{1,166} & \multirow{5}{*}{0,327} & \multirow{5}{*}{-} \\
\hline & Gida (2) & 52 & 3,92 & 0,69 & & & \\
\hline & Otomotiv (3) & 20 & 4,05 & 0,68 & & & \\
\hline & \begin{tabular}{|l|} 
Elektronik (4) \\
\end{tabular} & 118 & 4,02 & 0,53 & & & \\
\hline & \begin{tabular}{|l} 
Inşaat (5) \\
\end{tabular} & 4 & 3,39 & 0,59 & & & \\
\hline \multirow{5}{*}{ Yenilikçilik } & Ambalaj (1) & 36 & 3,72 & 0,66 & \multirow{5}{*}{5,462} & \multirow{5}{*}{$0,000 *$} & \multirow{5}{*}{$\begin{array}{l}2>1 \\
2>5 \\
2>4\end{array}$} \\
\hline & Gıda (2) & 52 & 4,15 & 0,53 & & & \\
\hline & \begin{tabular}{|l|} 
Otomotiv (3) \\
\end{tabular} & 20 & 3,74 & 0,59 & & & \\
\hline & \begin{tabular}{|l|} 
Elektronik (4) \\
\end{tabular} & 118 & 3,82 & 0,65 & & & \\
\hline & \begin{tabular}{|l|} 
İnşaat (5) \\
\end{tabular} & 4 & 2,96 & 0,99 & & & \\
\hline \multirow{5}{*}{ Genel yetenek } & Ambalaj (1) & 36 & 3,64 & 0,52 & \multirow{5}{*}{8,977} & \multirow{5}{*}{$0,000 *$} & \multirow{5}{*}{$\begin{array}{l}2>1 ; \\
2>4 ; \\
3>1\end{array}$} \\
\hline & Gıda (2) & 52 & 4,20 & 0,56 & & & \\
\hline & \begin{tabular}{|l|} 
Otomotiv (3) \\
\end{tabular} & 20 & 4,17 & 0,20 & & & \\
\hline & Elektronik (4) & 118 & 3,83 & 0,50 & & & \\
\hline & İnşaat (5) & 4 & 3,62 & 0,51 & & & \\
\hline
\end{tabular}

Gıda sektöründe çalışan orta düzey yöneticilerin yenilikçilik yaratmakta daha ileri olduğu görülmektedir. Gıda sektörü çok fazla değişkenliğin, farklı ürünlerin yer aldığı ve sürekli değişim geçiren bir sektördür. Otomotiv sektörünün puan ortalaması ambalaj sektörüne göre istatistiksel olarak farklılık göstermektedir $(p<0,05)$. Otomotiv sektörünün puan ortalamasının ambalaj sektörüne göre daha yüksek olduğu görülmüştür. Böylelikle "Yöneticilik yetkinlikleri ölçeğinden ve alt boyutlarından elde edilen ortalama puanları faaliyet sektörüne göre farklılık göstermektedir" şeklinde ifade edilen Hipotez 7 kabul edilmiştir.

\section{SONUÇ}

Bu araştırma, yöneticilere verilen zorlu görevler ve yönetici yetkinlikleri, geri bildirim alma, öğrenme odaklılık ve zorlu görevlere erişim üzerindeki etkilerini araştırmaya yönelik yapılmıştır. Literatür incelendiğinde yöneticilere verilen zorlu görevler işletmelerde yöneticilere verilmesi gereken zor görevler olarak nitelendirilmektedir. Bu zor görevler arasında yöneticilere alışılmadık sorumluluklar verilmesi, zor durumlarla baş edebilmeleri ve farklı stratejiler geliştirmeleri gibi sorumluluklar yer almaktadır. Yöneticilere verilen zorlu görevler yönetici geliştirmenin bir parçasıdır ve bu çalışmada yöneticilere verilen zorlu görevlerin ve yönetici yetkinliklerinin ortaya çıkarılması amaçlanmıştır. Buna bağlı olarak zorlu görevler ile ilgili tüm literatürdeki çalışmalar incelenmiş olup yönetici yetkinliklerinin arttırılmasını sağlayan faktörler bir araya getirilerek zorlu görevler kavramı bu çalışma ile yazına kazandırılmıştır.

Alan yazınında yöneticilere verilen zorlu görevler ile ilgili çalışmalara bakıldığında geri bildirim alma, gelişim özelliğine sahip zorlu görevlere erişim, öğrenme odaklılık ve yönetici yetkinlikleri değişkenlerinin bir arada değerlendirildiği bir çalışmaya rastlanmamaktadır. Çalışmada yöneticilere verilen zorlu görevler 10 boyut olarak incelenmiştir. Buna bağlı olarak yönetici yetkinlikleri ise 3 boyut olarak incelenmiştir. Türkçe alan yazınında ikisini bir arada ölçümleyen bir çalışmaya rastlanmamaktadır. Araştırmada yöneticilere verilen zorlu görevler kavramının ölçülmesinde Dragoni, Tesluk ve Oh'un (2009) ve DeRue ve Wellman'in (2009) çalışmalarında kullanılan yöneticilere verilen zorlu görevler ölçeği Türkçe'ye uyarlanmıştır. Zorlu görevler ölçeğinin 50 madde ve 5 boyut hali kullanılmıştır. Yönetici yetkinliklerinin ölçülmesinde Spreitzer'ın (1999) 3 boyuttan oluşan ölçeğinden yararlanılmıştır. Öğrenme odaklılık ölçeği 5 madde olarak geliştirilen VandeWelle (1997) anket sorularından yararlanılmıştır. Morgeson ve Humphrey’nin (2006) geliştirdiği 6 maddelik geri bildirim alma ölçeğinden 
yararlanılmıştır. Dragoni, Tesluk ve Oh'un (2009) yaptıkları çalışma için geliştirdiği 3 soruluk gelişim özelliğin sahip zorlu görevlere erişim ölçeğinden yararlanılmıştır.

Çalışmada kullanılan modelde yönetici yetkinlikleri (Spreitzer, 1997) 24 madde ve 3 boyut ile ölçülmektedir. Bu boyutlar; genel yetenek, girişimcilik ve yenilikçilik (Kaplan, 1997; McCall, Spreitzer ve Mahoney, 1997; Leslie, Dalton, Ernst ve Deal, 2002: 6) olarak tespit edilmiştir.

Yönetici yetkinlikleri, bu araştırmada yöneticilerin liderlik, entelektüel yeteneklerini geliştirici, idari becerilerini arttırıcı ve kişilerarası becerilerinin gelişimini destekleyici bir kavram olarak yer almaktadır (Spreitzer, 1997; Dragoni, 2009). Bu çalışmalardan yola çıkarak kavramsallaştırmayı oluşturan 6 boyut genel yetenek, iş bilgisi, kişilerarası beceri, bağlılık ve kültürler arası sorun çözme ve cesaret kavramları bir araya getirilerek kavram 3 boyut olarak genel yetenek, girişimcilik ve yenilikçilik olarak operasyonel hale getirilmiştir. Bu çalışmada yönetici yetkinlikleri ölçeğinin iç tutarlıık katsayısı $(\alpha=, 877)$ yüksek güvenirlik derecesine sahip olduğu tespit edilmektedir. Yapılan pilot çalışmada anketi cevaplayan uzmanlar, yönetici yetkinlikleri ölçeğinin maddeleri ve faktörleri üzerinde \%90 oranında onayı alınarak, ölçek içerik/kapsam geçerliliği açısından kullanılabilir hale gelmiştir. Bu çalışmada boyut bazında iç tutarlıık katsayıları sırasıyla girişimcilik boyutu $(\alpha=, 865)$; yenilikçilik boyutu $(\alpha=, 841)$ ve genel yetenek boyutu için $(\alpha=, 798)$ olup yüksek iç tutarlılık katsayısına sahiptirler. Dragoni ve ark. (2009) yapmış olduğu çalışmada Cronbach alfa değerleri yaptığımız çalışma ile büyük oranda örtüşmektedir. Genel yetenek $(\alpha=, 77)$; yenilikçilik boyutu $(\alpha=, 86)$ ve girişimcilik boyutu $(\alpha=, 85)$ olarak iç tutarlılık katsayılarına sahiptir. Doğrulayııı faktör analizine tabi tutulan ölçek maddelerinin 6 boyut altında toplandığı ve yapı geçerliliği sağladığı tespit edilmiştir. Araştırmanın sonucu olarak yönetici yetkinlikleri ölçeği bundan sonra yapılacak olan çalışmalarda 24 madde ve 3 boyut olarak kullanılabilecektir.

Yönetici yetkinlikleri kavramı yönetici geliştirme teorisi kapsamında yapılan çalışmalarda zorlu görevler (Dragoni, v.d., 2009) ve öğrenme odaklılık (DeRue ve Wellman, 2009) altında incelenen çalışmalarda yönetici yetkinliklerini geliştirici faktörler (genel yetenek, iş bilgisi, kişilerarası beceri, bağlılık ve kültürler arası sorun çözme ve cesaret) 6 faktör olarak temsil edilmekte bunun yanı sıra yapmış olduğum çalı̧̧ada yönetici yetkinliklerini arttırıcı faktörlerin 3 boyut (Leslie, Dalton, Ernst ve Deal, 2002) olarak (genel yetenek, yenilikçilik ve girişimcilik) ölçülebileceği tespit edilmiştir. Bu şekilde yönetici yetkinliklerinin kapsam açısından 3 boyutlu olarak ele alınması yöneticilerin geliştirilmesi için daha da kapsayıcı olmaktadır.

Araştırmada yöneticilere verilen zorlu görevler kavramının ölçülmesinde Dragoni vd. (2009) ile DeRue ve Wellman'in (2009) çalışmalarında kullanılan yöneticilere verilen zorlu görevler ölçeği Türkçe'ye uyarlanmıştır. Bu araştırma, yöneticilere verilen zorlu görevler ölçeğinin Türkçe'ye adapte edilmesi ve kullanılabilir hale gelmesi açısından önem taşımaktadır. íki farklı anket oluşturulması ve hem orta düzey yöneticilerden hem de üst düzey yöneticilerden veri sağlanması açısından diğer çalışmalardan ayrışmaktadır. Yöneticilere verilen zorlu görevler, yönetici yetkinlikleri ile geri bildirim alma, zorlu görevlere erişim ve öğrenme odaklılık kavramlarının niceleyici ilişkilerinin model aracılığıyla geliştirilmesi ve stratejik yönetim alanında yapılacak olan çalışmalara yol göstermesi açısından büyük öneme sahiptir.

Araştırma sonuçlarına göre yöneticilere verilen zorlu görevler ölçeğinin 24 madde ve 5 faktör ile ölçülebildiği tespit edilmiştir. Sonuçlar, yöneticilere verilen zorlu görevlerin 10 faktörlü bir ölçüm modeli geliştiren Dragoni vd. (2009) zorlu görevlerin çok faktörlü olarak ölçülmesine olanak vermekte ise de ölçmeyi kolaylaştıran 5 faktörlü (De Rue ve Wellman, 2009: 865) ölçeği kullanmanın ölçmeyi kolaylaştırdığı ve daha güvenilir sonuçlar verdiğine ulaşılmıştır. Bu nedenle bu çalışmada yöneticilere verilen zorlu görevler ölçeği 24 madde ve 5 boyuttan oluşmaktadır. Bu 5 boyut ise; (1) dış baskı ile başa çıkabilme, (2) yönetim alanı genişliği, (3) üst yönetimi etkileme, (4) iş gücü çeşitliliğini yönetme ve (5) zor şartlarda karar vermeden oluşmaktadır.

Araştırmanın kavramsal modeli test edildiğinde yöneticilere verilen zorlu görevlerin yönetici yetkinliklerini geliştirici güçlü bir etkisi olduğu görülmektedir. Bu sonuç ile işletmelerin yöneticilerine vereceği zorlu görevler ile üst düzey ve orta düzey yöneticilerinin yönetici yetkinliklerine geliştirici etki edebilecekleri söylenebilir. Literatürde geri bildirim almanın yönetici yetkinliklerini geliştirdiği, gelişimsel özelliğe sahip zorlu görevlere erişimin yönetici yetkinliklerini desteklediği, öğrenme odaklıı̆ın ise yönetici yetkinliklerini geliştirici ve öğrenmelerini kolaylaştıran 
bir etkisinin olduğu yapılan çalışmalarda tespit edilmiştir. Bu çalışma ile McCauley v.d (1994) çalışmasındaki sonuçların benzerlik gösterdiği görülmektedir.

Çalışmanın önemli bulgularından biri de yöneticilere verilen gelişimsel özelliğe sahip zorlu görevlere erişimin yönetici yetkinliklerini olumlu yönde artıırdığı ve yöneticilerin gelişmesinde büyük rol oynadığıdır. Bu doğrultuda Dragoni ve diğerlerinin (2009) yaptıkları çalısmada yöneticilere verilen gelişimsel özelliğe sahip zorlu görevler sayesinde yönetici yetkinliklerinin arttırabileceği sonucuna ulaşmışlardır. Bu araştırmada da Dragoni'nin çalışması ile paralel sonuçlar ortaya çıktığı görülmektedir.

Araştırma modelinde görüldüğü üzere yöneticilere verilen zorlu görevler ile yönetici yetkinlikleri arasında pozitif yönlü ilişki olduğu ve geri bildirim alma, öğrenme odaklılık ve gelişimsel özelliğe sahip zorlu görevlerin yönetici yetkinlikleri üzerinde istatistiksel açıdan pozitif ve anlamlı bir etkisinin olduğu görülmektedir. Boyut bazında bakıldığında; dı̧̧ baskı ile başa çıkabilme, üst yönetimi etkileyebilme ve iş gücü çeşitliliğini yönetme boyutlarının girişimcilik üzerinde etkisi olduğunu; zor şartlarda karar vermenin aynı zamanda yenilikçilik boyutu üzerinde etkisi olduğu tespit edilmiştir. Yönetici yetkinliklerinin artırılmasını sağlayan faktörlerin belirlenmesine yönelik az sayıda nicel çalışmaya rastlanmaktadır. Literatürdeki bu eksikliği gidermek amacıyla yönetici yetkinliklerini doğrudan etkileyen faktörlerin bir araya getirildiği ve kullanıldığı bir çalışma ortaya çıkarılmıştır.

Yöneticilere verilen zorlu görevler üzerine çalışma yapacak olan akademisyenler bu ölçeği farklı sektörlerde veya farklı departmanlarda uygulayarak işletmeler üzerine yönetici yetkinliklerini geliştirici faktörleri tespit edebilir veya test edebilirler. Bundan sonra yapılacak olan çalışmalarda yöneticilere verilen zorlu görevlerin alt boyutlarının işletmelerin farklı özellikleri ile değerlendirilmesi gerçekleştirilebilinir. Bunun yanı sıra yönetici yetkinliklerinin de farklı değişkenler ve kavramlarla ilişkileri dolaylı etkileri veya direkt etkileri test edilebilir hale gelmiştir. İşletmeler üzerinde etkili olabilecek yönetici yetkinliklerini geliştirici diğer değişkenler de incelenebilinir. Yöneticilerin seçiminde araştırmada kullanılan yönetici yetkinlikleri ölçeği insan kaynakları birimi tarafından kullanılabilinir. Bu doğrultuda işletmede görev alacak olan yöneticinin, işe uygunluğu, genel yetenekleri, kişisel becerileri, girişimcilik düzeyi tespit edilebilir. İ̧letmelerde mevcut durumda çalışan yöneticiler için de ölçek yardımıyla yönetici yetkinlikleri kazanımı konusunda hangi durumda oldukları ile durum tespiti yapılabilir. Bu bağlamda da yöneticilere verilecek olan eğitimler belirlenebilir. 


\section{KAYNAKLAR}

Ang, S., Dyne, L.V., Koh, C., ve Ng, K.Y. (2007). "Cultural Intelligence: Its measurement and effects on cultural judgment and decision making, cultural adaptation and task performance", Management and Organization Review,3/3, 335-371.

Antonovsky, A. (1987). "Health-promoting factors at work: The sense of coherence". Psychosocial Factors at work and their Relation on Health (Eds: R. Kalimo, M.A. El Batawi \& C.L.Cooper), World Health Organization, Geneva, pp. 153-167.

Aryee, S.C veChris W.L. (2012). “Antecedents and outcomes of challenging job experiences: a social cognitive perspective", Human Performance, 25, 215-234.

Aslam, U., Ilyas, M., Imran, M.K. ve Rahman, U.U. (2016). "Intelligence and its impact on managerial effectiveness and career success (evidence from insurance sector of Pakistan)", Journal of Management Development,35/4, 505-516.

Avcı, İ. (2004). Türk kamu yönetiminde yönetici geliştirme (Mülki idare amirleri örneği).(Yayımlanmış Doktora Tezi). Karadeniz Teknik Üniversitesi, Sosyal Bilimler Enstitüsü, Trabzon.

Barbuto, J.E. ve Wheeler, D.W. (2002). Becoming a servant leader. Do you have what it takes? NebGuide G021481, A. Lincoln: University of Nebraska, Nebraska Cooperative Extension.

Başalp, A.A. (2018).Yönetici Yetkinliklerinin Geliştirilmesinde Zorlu Görevler ve Erişimi Ile Öğrenme Odaklilik Ve Geri Bildirimin Rolü. (Yayımlanmış Doktora Tezi). Manisa Celal Bayar Üniversitesi, Sosyal Bilimler Enstitüsü, Manisa.

Başusta, H. (2006). Management development ın human resource management and a research.(Yayımlanmış Yüksek Lisans Tezi). Marmara ÜniversitesiSosyal Bilimler Enstitüsü, İstanbul.

Blake, Robert R., Mouton, Jane S., Barnes, Louis B., Greıner, Larry E. (1964).“Breakthrough in Organization Development", Harvard Business Review, 42/6, 133-155.

Bolt, J.F. (2007). Mapping The Future Leadership Development. The 2007 Pfeiffer Annual: Leadership Development, John Wiley and Sons, SanFrancisco, CA.

Campion, M.A., Cheraskin, L. ve Stevens, M.J. (1994). “Career-related antecedents and outcomes of job rotation”, Academy of Management Journal, 37, 1518-1542.

Charan, R., Drotter, S. ve Noel, J. (2011). The Leadership Pipeline: How To Build The Leadership Powered Company, Jossey-Bass.

Chien, T.C.(2007). "Technical competency needs assessment for the telecommunications professional”, Journal of Human Resource Adult Learn, 3/2, 90-96.

Dennis, S. R. (2004). Servant leadership theory: development of the servant leadership assessment instrument. (Doctoral dissertation). School of Leadership Studies, Regent University, Virginia.

DeRue, D.S.ve Wellman, N. (2009). "Developing leaders via experience: the role of developmental challenge, learning orientation, and feedback availability", Journal of Applied Pscyhology, 94/4, 859-875.

De Jong, J. ve Den Hartog, D. (2010). “Measuring Innovative work behavior”, Creativity and Innovation Work Behaviour. 19/1, 23-36.

Dragoni, L.,Tesluk, P.E., Russell, J.E.A.ve Oh, I. (2009). “Understanding managerial development: integrating developmental assignments, learning orientation, and Access to developmental opportunities in predicting managerial competencies", Academy of Management Journal, 52/4, 731-743.

Durusu, B.M. (2010). Yönetici geliştirme ve örgüt geliştirme: T.C. Ziraat bankası A.ş.'de bir uygulama.(Yayımlanmış Yüksek Lisans Tezi). Gazi Üniversitesi, Sosyal Bilimler Enstitüsü, Ankara.

Ford, J.K., Quinones, M., Sego, D.J.ve Speer-Sorra, J. (1992). “Factors affecting the opportunity to perform trained tasks on the job", Personnel Psychology, 45, 511-527.

Global Human Capital Trends (2016). The Ne Organization: Different by Design. (06.07.2016) www2.deloitte. com. 
Göncüler, Ş. (1996). Yönetici Yetiştirme ve Geliştirme Faaliyetlerinin Yönetim Sorunlarının Çözüme Katkısı. (Yayımlanmış Yüksek Lisans Tezi). Marmara Üniversitesi Sosyal Bilimler Enstitüsü İşletme Anabilimdalı, İstanbul.

Gupta, S. (1996). "Managerial effectiveness: conceptual framework and scale development", Indian Journal of Industrial Relations. 31/3, 392-409.

Gündüz, H. (1994). Yönetici Geliştirme ve Yönetici Geliştirmenin Yönetici Başarısına Katkısı. (Yayımlanmış Yüksek Lisans Tezi). Hacettepe Üniversitesi Sosyal Bilimler Enstitüsü, Ankara.

Hepkaya, S. (2000). Türk Ilaç Endüstrisinde Yönetici Geliştirme Faaliyetleri.(Yayımlanmış Yüksek Lisans Tezi). Ankara Üniversitesi, Sağlık Bilimleri Enstitüsü, Ankara.

Hsieh, H. ve Huang, J.T. (2018). "Exploring factors influencing employees' impression management feedback-seeking behavior: The role of managerial coaching skills and affective trust", Human Resource DevelopmentQuarterly, 29, 163-180; Wiley.

Katz, R. (1955). "Skills of an effective administrator", Harvard Business Review, 33, 33-42.

Kim, S., ve Kuo, M. H. (2015). "Examining the relationships among coaching, trustworthiness, and role behaviors a social exchange perspective", The Journal of Applied Behavioral Science, 51/2, 152-176.

Kocabey, U. (2010). İşletmelerde performans değerlendirme, geri bildirim, kariyer planlama ve örgütsel bağlılık arasındaki ilişkilere yönelik bir araştırma.(Yayımlanmış Yüksek Lisans Tezi). Gebze Yüksek Teknoloji Enstitüsü, Gebze, Kocaeli.

Law, K.S., Wong, C.S.ve Mobley, W.H. (1998). "Toward a taxonomy of multidimensional constructs", Academy of Management Review, 23, 741-755.

Leslie, B.L., Dalton, M, Ernst, C.ve Deal, J. (2002). Managerial effectiveness in a global context, Center for Creative Leadership, North Carolina, USA.

Maitland, I. (1998). Personelyönetimi(Çev: D. Uğur), Epsilon Yayınları, İstanbul.

Marşap, A. (1992). Yönetici Eğitimi. (Yayımlanmış Doktora Tezi). Istanbul Üniversitesi Sosyal Bilimler Fakültesi Işletme Fakültesi, İstanbul.

Matsuo, M. (2017). "The unlearning of managerial skills: a qualitative study of executive officers",European Management Review, 16/2, 303-315.

Mavondo, Felix T.,Chimhanzi, J. ve Stewart, J. (2005). "Learning orientation and market orientation relationship with innovation, human resouce practices and performance", European Journal of Hospitality Management, 17, 391-406.

McAllister, D. J. (1995). "Affect and cognitive-based trust as foundations for interpersonal cooperation in organizations",Academy of Management Journal, 38/1, 24-59.

McCall, M.W., Lombardo, M.M.ve Morrison, A.M. (1988). The Lessons of Experience: How Successful Executives Develop on The Job, Lexington Books, Lexington, MA.

McCall, M.W. (2004). "Leadership development through experience”, Academy of Management Executive, 18, 127-130.

McCall, M.W.ve Hollenbeck, G.P. (2002). Developing global executives: The lessons of international experience, Harvard Business School Press, Boston.

McCall, MW.,Spreitzer, G.M.ve Mahoney, J. (1997). Prospector, Center for Creative Leadership, Greensboro, NC.

McCauley, C.D. (1999). Job challenge profile participant workbook, John Wiley \& Sons, San Francisco.

McCauley, C.D. (2001). "Leader training and development”, The nature of organizational leadership, (Ed: Stephen Zaccaro, Richard J. Klimoski), Jossey-Bass, San Francisco.

McCauley, C.D., Ruderman, M.N.,Ohlott, P.J.ve Morrow, J.E. (1994). “Assessing the developmental components of managerial jobs", Journal of Applied Psychology,79, 544-560.

McLean, G. N., Yang, B., Kuo, C., Tolber, A., ve Larkin, C. (2005). "Development and initial validation of an instrument measuring coaching skill",Human Resource Development Quarterly, 16/2, 157-217. 
Minha, N. V., Badira, Y. F., Quangb, N. N. ve Afsarc, B. (2017)."The impact of leaders' technical competence on employees' innovation and learning", Journal of Engineering and Technology Management, 44, 44-57.

Morgeson, F.P.ve Humphrey, S.E. (2006). "The Work Design Questionnaire (WDQ): developing and validating a comprehensive measure for assessing job design and the nature of work", Journal of Applied Psychology, 91/6, 1321-1339.

Öner, Z.H. (2008). The mediating effect of organizational justice: moderating roles of sense of coherence and job complexity on the relationship between servant leadership, and work engagement. (YayımlanmamışDoktoraTezi). Marmara Üniversitesi, İstanbul.

Page, D. ve Wong, T.P. (2000). "A conceptual framework for measuring servant leadership", The human factor in shaping the course of history and development, (Eds: B. S. AdjGibolosoo), University Press of Americalnc., New York, pp.109-141.

Peker, Ö. (1994). Yönetici Eğitimi, Türkiye ve Orta Doğu Amme İdaresi Enstitüsü ÜçBilek Matbaası, Ankara.

Rubin, R.S. ve Dierdorff, E.C. (2009). "How relevant is the MBA? assessing the alignment of required curricula and requiredmanagerial competencies", Academy of Management Learning \& Education, 8/2 (Jun.), 208-224.

Seibert, S.E., Sargent, L.D.,Kraimer, M.L.veKiazad, K. (2017). “Linking Developmental Leader Effectiveness and Promotability: The Mediating Role of Leadership Self-Efficacy and Mentor Network",Personnel Psychology, 70, 357-397.

Spreitzer, G.M., McCall, M.W.ve Mahoney, J.D. (1997). "Early identification of international executive potential”, Journal of Applied Psychology, 82, 6-29.

Sherer, M. ve Adams, C. H. (1983). "Construct validation of the Self-efficacy Scale", Psychological Reports, 53, 899-902.

Tesluk, P.E.ve Jacobs, R.R. (1998). "Toward an integrated model of work experience", Personnel Psychology, 51/2, 321-355.

Torrington, D. ve Heil, L. (1995). "Personel Management", HRM in Action.

Tsang, E. ve Zahra, S. (2008). “Organizational unlearning”,Human relations, 61, 1435-1462.

Turban, D. ve Dougherty, T. (1994). "Role of protege personality in receipt of mentoring and career success", Academy of Management Journal, 37/3, 688-702.

Uygur, H. (1996). Yönetici Geliştirme ve Yönetici Eğitimi. (Yayımlanmış Yüksek Lisans Tezi). Yıldız Teknik Üniversitesi Sosyal Bilimler Enstitüsü, İstanbul.

VandeWalle, D. (1997). "Development and validation of a work domain goal orientation instrument", Educational and Psychology Measurement, 57, 995-1015.

Velsor, E.V., Wilson, M., Criswell, C.ve Chandrasekar, A. (2013). "Learning to lead: a comparison of developmental events and learning among managers in China, India and the United States", Asian Business and Management, 12/4, 455-476.

Wakefield, N.,Abbatiello, A., Agarwal, D.,Pastakia, K.veBerkelV.A. (2016). "Leadership awakened: generations, teams, science", Global Human Capital Trends 2016 Report, Deloitte insights.

Wechsler D. Wechsler Adult Intelligence Scale-Fourth Edition. Pearson; San Antonio, TX: 2008.

\section{Beyan ve Açıklamalar (Disclosure Statements)}

1. Bu çalışmanın yazarları, araştırma ve yayın etiği ilkelerine uyduklarını kabul etmektedirler (The authors of this article confirm that their work complies with the principles of research and publication ethics).

2. Yazarlar tarafından herhangi bir çıkar çatışması beyan edilmemiştir (No potential conflict of interest was reported by the authors).

3. Bu çalışma, intihal tarama programı kullanılarak intihal taramasından geçirilmiştir (This article was screened for potential plagiarism using a plagiarism screening program). 